\title{
A CERÂMICA COMUM ROMANO-REPUBLICANA DE Monte Molião (Lagos)
}

\author{
Elisa de Sousa \\ Ana Margarida Arruda \\ Uniarq - Centro de Arqueologia. Universidade de Lisboa
}

Recibido: 23/01/2014

Revisado: 05/02/2014
Aceptado: 03/03/2014

Publicado: 20/05/2014

\section{RESUMO}

As escavações realizadas em Monte Molião (Lagos, Algarve, Portugal), entre 2006 e 2011, permitiram datar a sua ocupação romano-republicana entre o último terço do século II e as primeiras décadas do século I a.n.e.

A cerâmica comum que foi recuperada nestes níveis é muito significativa em termos numéricos e algumas das suas características permitem avançar dados concretos sobre os vários circuitos comerciais que envolveram a costa sul do actual território português, durante esse período. O conjunto é constituído por cerâmica de produção local (maioritariamente a torno), da península itálica, mas também, e sobretudo, por importações do actual território espanhol (baía de Cádis, Guadalquivir e costa oriental).

\section{Palavras Chave}

Cerâmica comum; Romano-republicano; Algarve; Monte Molião
ABSTRAC

Excavations carried out at Monte Molião(Lagos, Algarve, Portugal) between 2006 and 2011 allowed to date its Roman Republican occupation between the last third of the 2 nd and the first decades of the 1st century BCE.

The common ware recovered in these levels is quite significant and some of its features made possible to advance new concrete data on the commercial network that involved the Portuguese South coast during this phase. The set consists of local (mainly well-made pottery) and italic productions, but also and mainly by imports from the Spanish territory (Cadiz Bay, Guadalquivir and East coast).

\section{KEYWORDS}

Common ware; Roman-republic; Algarve; Monte Molião

el@fl.ul.pt 


\section{INTRODUÇÃO}

A análise detalhada de conjuntos de cerâmica comum, sobretudo quando estão devidamente contextualizados estratigraficamente, permite estabelecer cronologias específicas para determinados tipos de formas, o que é de grande utilidade, não apenas para o caso concreto do sítio de que são provenientes, mas também para outros, de mais difícil datação intrínseca.

Por outro lado, a cerâmica comum permite analisar, sob novas perspectivas, as redes de comércio de âmbito local e regional e compreender aspectos da actividade quotidiana das comunidades que habitaram determinadas áreas num momento concreto, tendo em consideração também o seu carácter pluri-funcional.

O estudo deste conjunto só se tornou possível pelo facto de estes materiais estarem inequivocamente associados, em contextos primários de ocupação, a outros (cerâmica campaniense, de paredes finas e ânforas) que possibilitavam a atribuição de cronologias bastante precisas, concretamente de finais do séc. II a.n.e. até às primeiras duas décadas do seguinte. No entanto, a sua sistematização enfrentou vários tipos de dificuldades, que se prenderam não só com o próprio conceito de "cerâmica comum”, e assim com a selecção dos materiais a incluir no estudo, mas também com a escassez de estudos tipológicos desta categoria cerâmica, especialmente para o período em análise, o que dificultou a classificação e a denominação das morfologias identificadas.

\section{Metodologia E CARACTERIZAÇão do CONJUNTO}

O conjunto analisado neste trabalho inclui todos os fragmentos cerâmicos recolhidos nas unidades

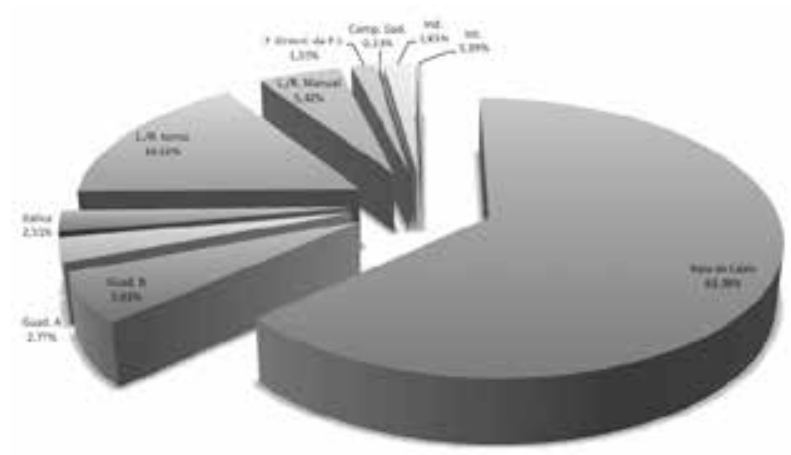

Figura 1. Distribuição dos grupos de fabrico identificados no conjunto de cerâmica comum da fase romanorepublicana de Monte Molião (base NMI). estratigráficas da fase romano-republicana de Monte Molião, incluindo os pintados e de fabrico manual, e que não cabem nas restantes categorias, nomeadamente nas ditas finas (campaniense, megárica, de tipo Kuass, paredes finas), nas de iluminação (lucernas) e nas de transporte (ânforas e as suas tampas).

O método de quantificação utilizado foi a contabilização do Número Mínimo de Indivíduos (NMI), que segue os critérios propostos por Arcelin e Tuffreau-Libre (1998).

A cerâmica comum do Monte Molião foi dividida, numa primeira fase, de acordo com as características dos seus fabricos e, posteriormente, em tipos morfo-funcionais. Dentro de cada um destes tipos, procurámos distinguir as principais variantes, com base no perfil geral da peça e nas particularidades de elementos específicos (bordo, colo, carena, etc.). Sempre que possível, estabeleceu-se a respectiva correspondência com quadros tipológicos já existentes.

Uma última referência é necessária em relação à dicotomia entre a "cerâmica pintada" e a cerâmica comum. De facto, apesar de nos contextos sidéricos mais arcaicos tal distinção traduzir realidades efectivamente diversas, uma vez que há uma clara diferenciação formal e funcional entre os vasos que foram assim decorados e os que o não foram, a partir de meados do $1^{0}$ milénio a.n.e., esta divisão perde a sua eficácia. Com efeito, nos repertórios artefactuais datados a partir, grosso modo, do século V a.n.e., são extremamente raras as formas que são exclusivamente pintadas, podendo o mesmo tipo morfológico apresentar, ou não, esse tipo de decoração, o que indica que a mera presença desse elemento não é discriminativo do ponto de vista funcional.

O conjunto da cerâmica comum do Monte Molião é composto por 2295 fragmentos, que correspondem a 1551 indivíduos. Distribuem-se por fragmentos de bordo, asa, fundo e parede.

Quanto às produções identificámos: 1443 fragmentos (983 NMI) da baía de Cádis, 348 (250 NMI) locais/regionais a torno, 123 (84 NMI) locais/regionais de fabrico manual, 182 (92 NMI) de uma área ainda indeterminada que, pensamos, se localiza na bacia do Guadalquivir (Grupo Guadalquivir B), 68 (43 NMI) também dessa mesma área, correspondentes ao seu fabrico mais característico (Grupo Guadalquivir A), 44 (39 NMI) itálicas, 28 (24 NMI) da costa oriental da Península Ibérica, 2 (2 NMI) da Campiña Gaditana e, finalmente, 51 frag- 
mentos (28 NMI) aos quais não foi possível atribuir uma proveniência específica. Resta ainda referir 6 outras peças $(6 \mathrm{NMI})$ que correspondem a intrusões de períodos mais recentes.

Por último, resta referir que não considerámos pertinente a apresentação de paralelos formais e de fabrico para as nossas peças, dada a ausência, no território actualmente português, de conjuntos publicados com esta cronologia. Contudo, não podemos deixar de mencionar que o Castelo da Lousa ofereceu um conjunto significativo de vasos, sobretudo de produção local e regional, que apresentam formas e funcionalidades idênticas às detectadas em Monte Molião, ainda que seja consideravelmente mais tardio do que o que é agora estudado (Pinto e Schmitt, 2010).

\section{Produções gaditanas}

As produções da baía de Cádis são as mais numerosas entre o conjunto de cerâmica comum do Monte Molião (1443 fragmentos - 983 NMI), representando $63,38 \%$. Correspondem a pastas brandas, porosas e arenosas, de textura fina, mediamente depuradas, com tonalidades que variam entre o castanho amarelado e o bege rosado. Dada alguma heterogeneidade que se verifica ao nível das colorações e acabamentos, não é de rejeitar a possibilidade de serem provenientes de diferentes centros de produção, ainda que provavelmente localizados numa mesma área geográfica (área de Cádis).

As cerâmicas comuns produzidas nesta zona durante o final da Idade do Ferro e o início do período republicano foram recentemente sistematizadas (Sáez Romero, 2005), tendo sido estabelecido um quadro tipológico para as principais formas gaditanas, com base nos exemplares recolhidos no Castillo de Doña Blanca, em Las Cumbres, e nos fornos de Torre Alta.

A quase totalidade dessas formas gaditanas são também identificáveis entre o conjunto do Monte Molião. Foi, no entanto, possível observar a existência de determinadas particularidades em termos de perfis das peças e secções de bordos que permitem a distinção de algumas variantes não contempladas na tipologia referida.

\subsection{Tigelas}

A forma mais representativa entre as produções da baía de Cádis é, sem dúvida, a tigela de perfil semi-hemisférico, com bordos simples e de secção arredondada, podendo apresentar, com alguma frequência, algum engrossamento interno ou externo.
Corresponde ao tipo GDR 1.2.1 de Sáez Romero (2005). Os seus diâmetros de bordo oscilam entre os 90 e os $204 \mathrm{~mm}$, situando-se a média entre os 150 e os $160 \mathrm{~mm}$.

A sua expressividade quantitativa no conjunto de cerâmica comum é digna de nota 605 fragmentos - $604 \mathrm{NMI}$ ), sendo a forma mais frequente em todo o conjunto. Esta tendência foi já constatada entre o espólio artefactual dos níveis mais tardios da Idade do Ferro não só de Monte Molião, mas também de outros sítios da costa algarvia (Sousa, 2009; Sousa e Arruda, 2011), observando-se assim uma clara continuidade com a fase anterior.

Entre o conjunto do Monte Molião foi possível recuperar seis exemplares de perfil completo, que estabelecem que os fundos podem ser planos ou ligeiramente convexos, apresentando invariavelmente um pé destacado. A altura destes vasos varia entre os 57 e os $66 \mathrm{~mm}$ e o diâmetro do fundo entre os 51 e os $60 \mathrm{~mm}$.

A maioria dos exemplares integrados nesta forma não exibe vestígios de decoração, com a excepção de alguns escassos fragmentos que se encontram pintados com bandas estreitas de tom vermelho ou vermelho-acastanhado. Estas podem surgir quer na parede interna quer na externa e ainda sobre o bordo.

Uma outra variante deste tipo de vasos, com o bordo apontado, também está presente no conjunto (55 fragmentos - $54 \mathrm{NMI}$ ), constituindo a segunda morfologia de tigela mais bem representada (18676, 13645, 11069, 13640, 11334, 13663, 13938, 11079), correspondendo ao tipo GDR 1.2.2 (Sáez Romero, 2005). O diâmetro do bordo oscila entre os 129 e os $159 \mathrm{~mm}$.

Mais escassas são as tigelas de paredes tendencialmente rectas e oblíquas do tipo GDR 1.2.3 (Sáez Romero, 2005) (13 fragmentos - 13 NMI), cujos diâmetros de bordo variam entre os 114 e os 135 mm (10973, 13934). Uma delas apresenta um perfil completo, com fundo ligeiramente convexo e pé destacado, tendo uma altura de $60 \mathrm{~mm}$ e um diâmetro de fundo de $48 \mathrm{~mm}$.

Deve referir-se ainda a presença de três exemplares (3 NMI) integráveis neste tipo morfo-funcional que exibem características que os distinguem das variantes anteriormente referidas.

Um deles caracteriza-se pela presença de um bordo bem assinalado ao nível da superfície externa (11073), com um diâmetro de $138 \mathrm{~mm}$. Outro destaca-se pela sua dimensão, que é consideravelmente maior quando comparada com os tipos anteriores 

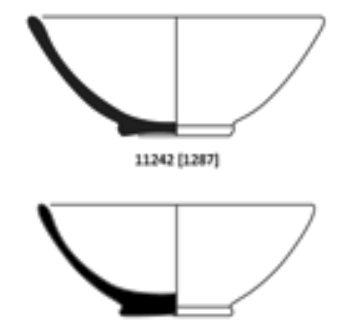

145e2 (12:5)

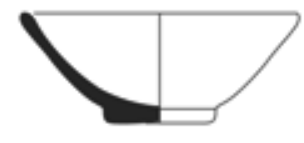

11209 [12a)]

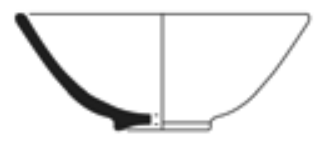

1124) [128]

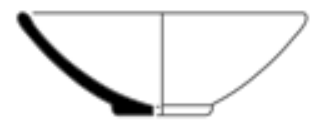

12579 (2)44)
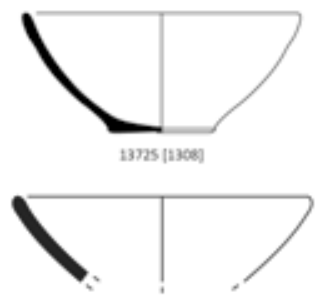

2313 [194]

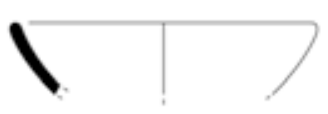

$124664263\}$

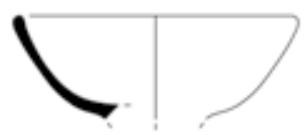

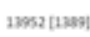

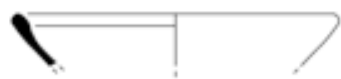

มมงค [ม299]

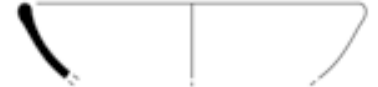

$12112[1262]$

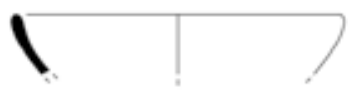

11332 (1266)

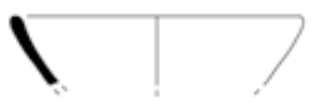

มมง [1209]

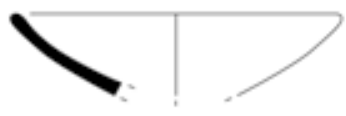

12071 (1385)
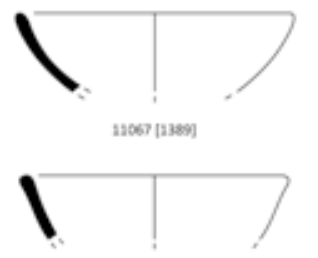

12506 [2290]
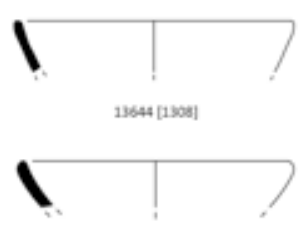

11321 (126)
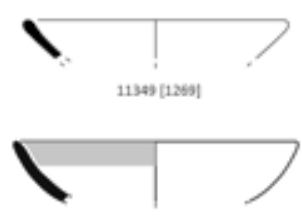

1ns \{1121

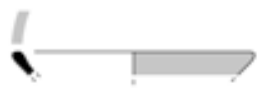

12ะมะ|เลวง|

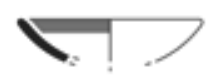

14909 [1200!
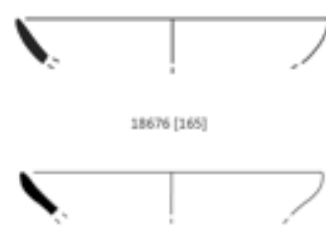

23605 [3068]
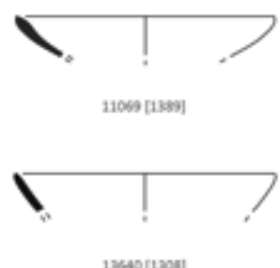

1960[1300!
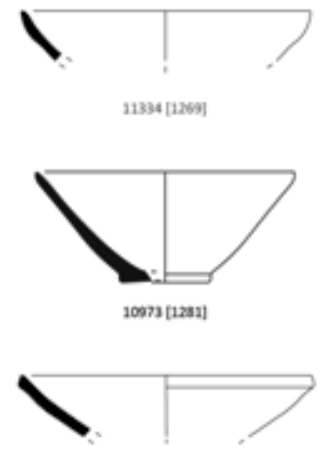

$13663[1309]$

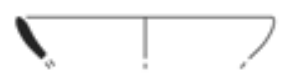

19as (1326)
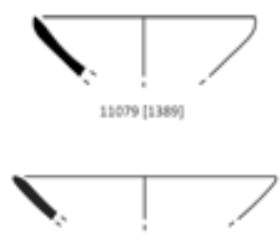

13934[1396]

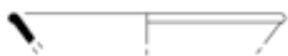

120กเมละด
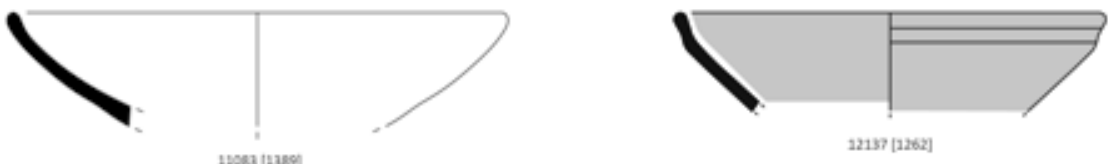

1.0อง เมละด

$12197[1262]$

Castanhoserermethado vermetho

Figura 2. Produções da baía de Cádis (tigelas). 
(11083). O seu diâmetro de bordo é de $255 \mathrm{~mm}$. O último distingue-se pela presença de uma carena bem assinalada na superfície externa, apresentando ainda um engobe de tonalidade castanha-avermelhada em ambas as superfícies (12137). O diâmetro de bordo é de $219 \mathrm{~mm}$.

Estes recipientes, genericamente integráveis na designação de tigelas, poderiam, em termos funcionais, ter diversos usos, desde o consumo de alimentos à mesa até à preparação e confecção de alimentos. Uma utilização paralela, enquanto tampas, foi também já proposta (Sáez Romero, 2005, p. 150).

A sua utilidade enquanto indicador cronológico é, contudo, muito escassa, uma vez que o início da sua produção remonta a fases arcaicas da Idade do Ferro, durante as quais esta morfologia é fabricada não só em cerâmica comum mas também em cerâmica cinzenta ou de engobe vermelho. A sua extensa diacronia de utilização não parece estar marcada pela evolução de aspectos estilísticos concretos, apesar da aplicação de bandas pintadas ser uma característica mais frequente sobretudo a partir de meados do $1^{\circ}$ milénio a.n.e. (Sáez Romero, 2005, p. 150).

\subsection{Pequenas taças}

Neste tipo morfo-funcional, integram-se pequenos recipientes de perfil também genericamente hemisférico, mas de formato bastante mais reduzido que os anteriores, com paredes arqueadas e bordo vertical ou reentrante, que pode apresentar uma secção circular ou apontada. Equivale aos tipos GDR 1.1.1 e 1.1.2 de Sáez Romero (2005).

Constituem uma forma pouco representada no conjunto (21 fragmentos - 21 NMI - 12125, 11212, $10963,14637,11940)$. Os seus diâmetros de bordo oscilam entre os 90 e os $116 \mathrm{~mm}$.

Esta morfologia remonta também ao período pré-romano, concretamente ao século IV a.n.e. (Bernal Casasola et al, 2003), podendo ter sido inspirada nos "saltcellar" gregos (Sáez Romero, 2005 , p. 149), que foram também produzidos em cerâmica de "tipo Kuass" (Niveau de Villedary y Mariñas, 2003a), tendo em ambos casos sido utilizados à mesa para conter condimentos ou molhos. Esta mesma função poderá ter sido desempenhada pelos exemplares de cerâmica comum (Sousa, 2009, p. 78), sendo também de considerar a sua utilização como lucerna, uma vez que, em alguns exemplares recolhidos no sul peninsular, há marcas de combustão na superfície interna e junto ao bordo, que por vezes está desbastado (Sáez Romero, 2005, p. 149; Maia, 2007; Sousa, 2009, p. 78).
Entre o conjunto destas taças, existem duas (2 $\mathrm{NMI}$ ) que se diferenciam das anteriores, podendo corresponder a variantes ainda não distinguidas na área gaditana.

Uma delas mantém as características já enunciadas, mas o bordo, com um diâmetro de $93 \mathrm{~mm}$, apresenta-se ligeiramente destacado na superfície externa (11941).

Uma outra (21310), de perfil mais globular, faz recordar, em termos da forma geral, materiais típicos da chamada "área turdetana" (Ferrer Albelda e García Fernández, 2008, p. 210 - n. ${ }^{\circ}$ 6), apesar das suas dimensões serem consideravelmente inferiores. Este vaso apresenta ainda um engobe de tonalidade violácea na superfície externa. O seu diâmetro de bordo é de $111 \mathrm{~mm}$.

\subsection{Grandes taças}

Neste grupo engloba-se um conjunto de recipientes abertos, de dimensões consideráveis, sendo geralmente marcados, na parte superior, por uma carena. O bordo é, geralmente, vertical ou reentrante, podendo apresentar algum engrossamento. Equivale aos tipos GDR 2.1.1 e 2.1.2 de Sáez Romero (2005).

O primeiro destes tipos (GDR 2.1.1), o mais bem representado, apresenta uma carena mais acentuada e bem marcada em ambas as superfícies (9 fragmentos - $9 \mathrm{NMI}$ ). Os seus diâmetros de bordo oscilam entre os 266 e os $285 \mathrm{~mm}$ (18770, 11394, 10960, 24274, 10959).

O tipo GDR 2.1.2, menos frequente, tem uma carena mais suave, o que lhe confere um perfil mais arredondado ( 2 fragmentos - 2 NMI). Os seus diâmetros de bordo variam entre os 222 e os $297 \mathrm{~mm}$ (14821, 11395).

Em termos cronológicos, a produção destes vasos está atestada, a partir do século IV a.n.e, na área da baía gaditana, concretamente no centro produtor de Villa Maruja (Bernal et al. 2003), perdurando durante, pelo menos, as duas centúrias seguintes (Sáez Romero, 2005, p. 151).

A utilização destes recipientes parece traduzir alguma multifuncionalidade. A sua dimensão sugere o seu uso na preparação e na confecção de alimentos, não sendo, contudo, de excluir a possibilidade de ter integrado também o serviço de mesa. A utilização pontual de alguns destes exemplares como tampas foi também já sugerida (Sáez Romero, 2005, p. 151).

\subsection{Almofarizes}

Neste grupo morfo-funcional, foram incluídos recipientes abertos, com paredes espessas e oblí- 


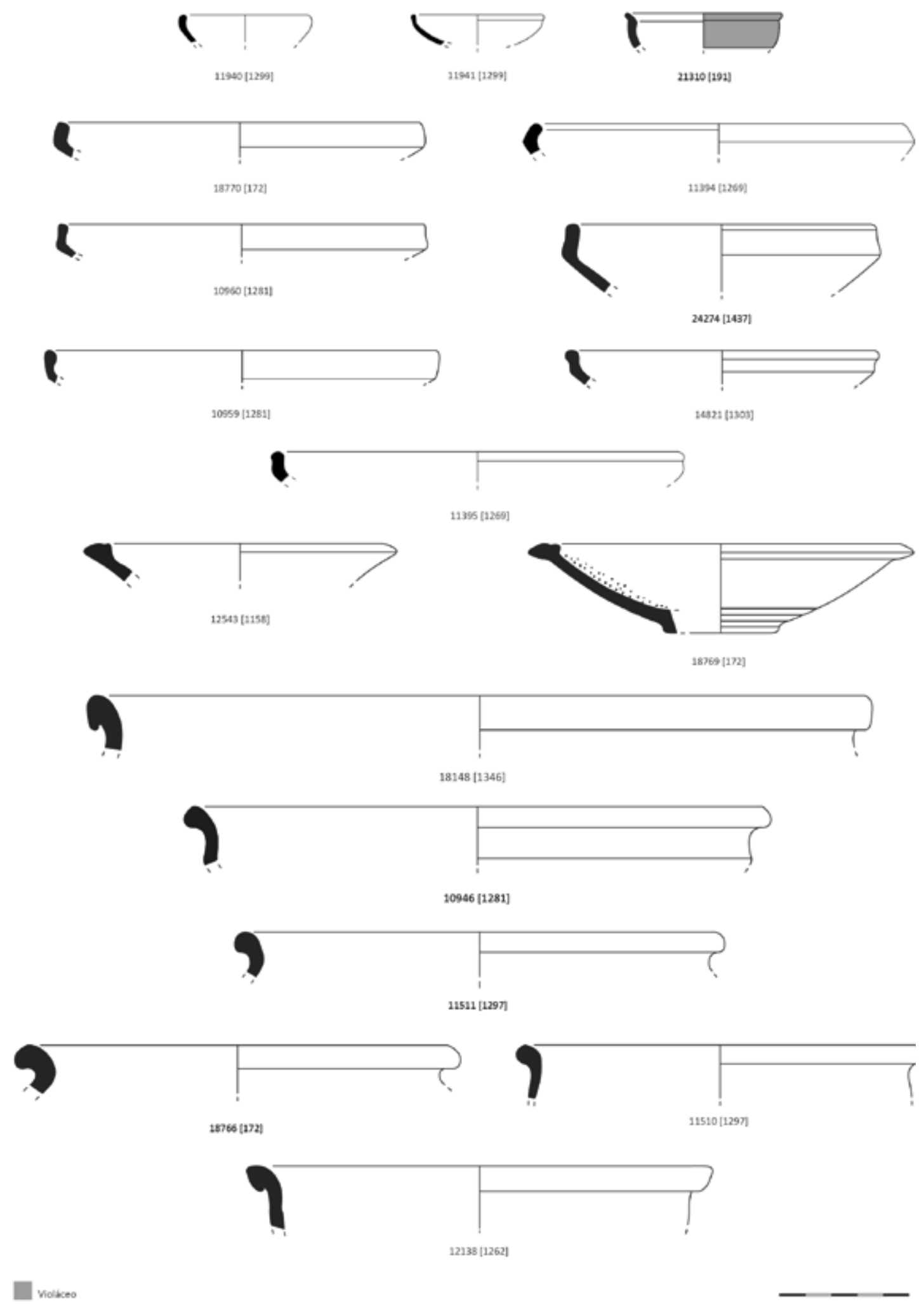

Figura 3. Produções da baía de Cádis (pequenas taças, grandes taças, almofarizes, bacias e/ou alguidares). 
quas, diâmetros amplos e fundos maciços e anelares. A sua superfície interna encontra-se geralmente incrustada com pequenos elementos pétreos que facilitam o atrito. O bordo é exvertido, de secção ovalada, espessado e aplanado. $\mathrm{Na}$ sua parte superior, exibe ainda um pequeno sulco. Integra a forma GDR 3.1.1 (Sáez Romero, 2005).

A sua representatividade é escassa no conjunto (7 fragmentos - 7 NMI) e os diâmetros de bordo variam entre os 210 e os $261 \mathrm{~mm}(12543,18769)$. Um exemplar bem conservado apresenta ainda um perfil completo, tendo uma altura de $66 \mathrm{~mm}$ e um diâmetro de fundo de $75 \mathrm{~mm}$.

A funcionalidade destes vasos prende-se principalmente com a preparação de alimentos, sendo usado para triturar, moer e misturar.

Apesar de a produção de almofarizes na área gaditana estar documentada desde meados do $1^{0}$ milénio a.n.e., este tipo morfológico específico parece ser característico de uma fase mais tardia, concretamente entre os séculos IV ao séc. II a.n.e. (Sáez Romero, 2005, p. 152).

\subsection{Bacias e/ou alguidares}

Os materiais integráveis neste grupo correspondem a vasos abertos, de grandes dimensões e consideravelmente profundos. Partilham um bordo invariavelmente exvertido, que pode formar um pequeno lábio.

Entre os materiais do Monte Molião, julgámos poder reconhecer dois tipos de perfis diferenciados.

O primeiro ( 9 fragmentos - $9 \mathrm{NMI}$ ) é marcado pela presença de uma carena na parte superior da peça, logo a seguir ao bordo, sendo este espessado, de secção ovalada (18148) ou arredondada (10946, 11511, 18766). Equivale à forma GDR 4.1.1 (Sáez Romero, 2005). Os seus diâmetros de bordo variam entre os 342 e os $423 \mathrm{~mm}$.

Cronologicamente, este tipo de alguidares surge também em meados do $1^{0}$ milénio a.n.e., perdurando até, pelo menos, ao século II a.n.e. (Sáez Romero, 2005).

Outros exemplares integrados neste tipo morfo-funcional exibem um perfil geral hemisférico ( 6 fragmentos - $6 \mathrm{NMI}$ ), mantendo os bordos as mesmas características da variante anterior (11510, 12138). Os seus diâmetros de bordo oscilam entre os 285 e os $330 \mathrm{~mm}$.

Resta referir ainda um outro (1 NMI), que parece também corresponder a uma bacia/alguidar (13626), exibindo, contudo, um perfil diferente, uma vez que possui um lábio pendente e triangu- lar, a partir do qual se desenvolvem paredes mais oblíquas. No entanto, atendendo as diminutas dimensões do fragmento, esta classificação é feita com algumas reservas. O seu diâmetro de bordo é de $285 \mathrm{~mm}$.

Em termos funcionais, estes tipos de bacias e/ ou alguidares estavam relacionados com actividades de preparação e confecção de alimentos (Niveau de Villedary y Mariñas 2003b, p. 14), não sendo de excluir a possibilidade de desempenharem também funções de armazenamento e de higiene pessoal (Sousa, 2009, p. 83).

No território peninsular, estes vasos começam a surgir, de forma sistemática, nos conjuntos artefactuais a partir do século VI a.n.e., mantendo, em linhas gerais, as mesmas características morfológicas até ao século II a.n.e. (Sáez Romero, 2005, p. 154).

\subsection{Pratos}

Nesta categoria englobaram-se recipientes abertos e pouco profundos, cujas características morfológicas permitem uma divisão em três grupos diferenciados.

$\mathrm{O}$ primeiro (1 NMI), tem um bordo simples e exvertido, apenas ligeiramente engrossado (13750). Destaca-se ainda a presença de um engobe castanho -avermelhado, que cobre ambas as superfícies. O seu diâmetro de bordo é de $180 \mathrm{~mm}$.

No segundo grupo, que inclui também um único exemplar (1 NMI), o bordo é indiferenciável da parede, tendo esta uma orientação tendencialmente oblíqua (1352). O seu diâmetro de bordo é de $243 \mathrm{~mm}$.

No terceiro, mais bem representado, englobamse as tradicionais morfologias dos "pratos de peixe", com um lábio pendente triangular, que pode ter uma terminação apontada ou mais arredondada, e paredes rectas e oblíquas ( 25 fragmentos - $23 \mathrm{NMI}$ ). Integram o tipo GDR 5.1.1 (Sáez Romero, 2005). Apresentam, geralmente, uma depressão no seu fundo interno, que, tal como foi proposto para o caso dos protótipos áticos (Sparkes e Talcott, 1970, p. 147; Aranegui Gascó, 1996, p. 401), seria utilizada para o escoamento ou para a recolha de molhos.

Os diâmetros de bordo variam entre 132 e 189 $\mathrm{mm}$. Um destes pratos, com um engobe de tonalidade violácea na superfície interna e na superfície externa lábio, tem um perfil completo, apresentando uma altura de $39 \mathrm{~mm}$ e um diâmetro de fundo de $51 \mathrm{~mm}$.

Este último tipo inspira-se seguramente nos pratos de peixe áticos de finais do século $\mathrm{V}$ e IV a.n.e. (Sparkes e Talcott, 1970), tal como nos do 


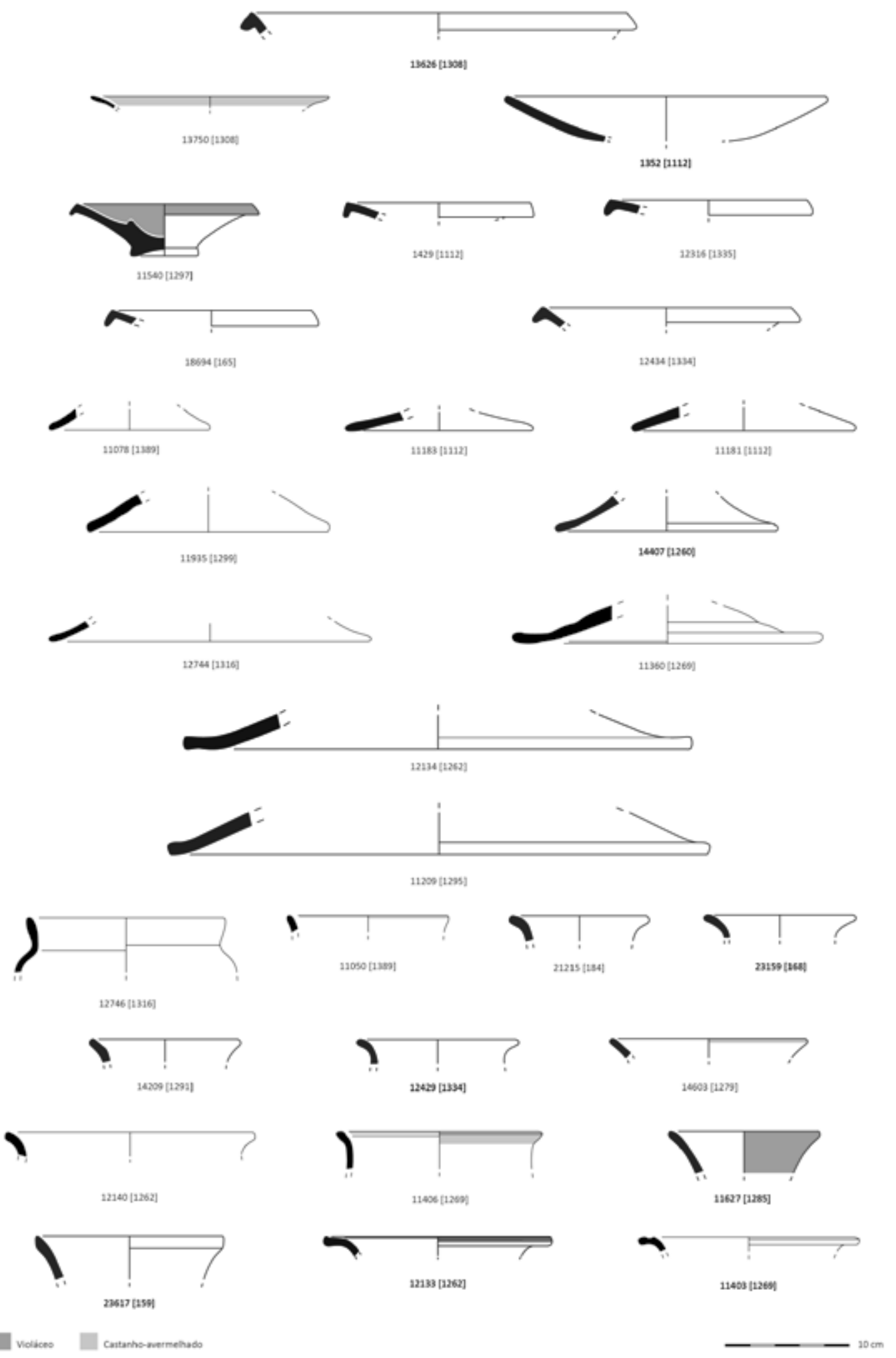

Figura 4. Produções da baía de Cádis (bacias e/ou alguidares, pratos, tampas, potes e/ou panelas). 
tipo II de cerâmica de Kuass (Niveau de Villedary y Mariñas, 2003a), categoria que teve, contudo, mais sucesso do que as produções de cerâmica comum. Estas últimas parecem surgir no registo artefactual sobretudo a partir do séc. IV a.n.e. (Bernal Casasola et al, 2003; Sáez Romero, 2005, p. 155).

\subsection{Tampas}

Entre o conjunto da cerâmica comum de Monte Molião, registam-se alguns fragmentos que apresentam características que possibilitaram a sua interpretação como tampas. As suas particularidades morfológicas permitiram a distinção de dois grupos, que apresentam semelhanças com a forma GDR 6 (Sáez Romero, 2005).

$\mathrm{O}$ primeiro tem paredes tendencialmente rectas (20 fragmentos - $20 \mathrm{NMI}$ ), terminando em bordos simples $(11078,11183,11181,11935)$. Os diâmetros variam entre 120 e os $183 \mathrm{~mm}$.

Outros exemplares, menos frequentes, apresentam um bordo mais aplanado (11 fragmentos - 11 $\mathrm{NMI}$ ), o que confere à parede uma tendência convexa $(12744,11360,14407,12134,11209)$, oscilando os diâmetros entre os 222 e os $411 \mathrm{~mm}$.

\subsection{Potes e/ou panelas}

Este tipo morfo-funcional é um dos mais difíceis de sistematizar entre os conjuntos de cerâmica comum. Engloba peças que podem ter funcionalidades diversas (serviço de mesa, confecção de alimentos, armazenagem), mas que, dado o seu grau de fragmentação e a ausência de sinais que indiquem a exposição ao fogo, dificilmente se podem distinguir. Por outro lado, potes e panelas exibem perfis muito similares e dificilmente diferenciáveis, não sendo impossível considerar que possam combinar ambas as funções.

Um outro aspecto que deve ser discutido, especificamente no que diz respeito às produções da baía gaditana, relaciona-se com a resistência destas pastas à exposição ao fogo. A natureza calcária das argilas é considerada, por alguns investigadores, como um obstáculo à sua utilização como panelas, uma vez que dificilmente suportariam temperaturas elevadas (Pinto, 2004, p. 13), o que implicava que tal função seria desempenhada por outras produções mais robustas, locais e/ou regionais, sendo os exemplares gaditanos utilizados, sobretudo, no armazenamento.

Entre os vasos integrados neste tipo, foi possível distinguir diferentes morfologias.

Um primeiro partilha bordos simples, de tendência vertical ou exvertida. Entre estes, distingue- se uma variante de perfil aparentemente globular e colo ligeiramente estrangulado (3 fragmentos - $3 \mathrm{NMI}$ ). O bordo é simples e de tendência vertical, sendo pouco diferenciado da restante parede (12746, 11050). Os seus diâmetros de bordo oscilam entre os 129 e os $156 \mathrm{~mm}$.

Outros, mais bem representados no conjunto, apresentam um bordo mais exvertido, por vezes ligeiramente espessado, e um colo um pouco mais longo (17 fragmentos - $17 \mathrm{NMI}$ ). Infelizmente, o elevado estado de fragmentação não permite tecer considerações sobre o perfil geral da peça (21215, 23159, 14209, 12429, 14603, 12140, 11406). Um dos exemplares exibe pintura castanha-avermelhada junto ao bordo, tanto na superfície interna como externa. Os seus diâmetros de bordo variam entre os 99 e os $198 \mathrm{~mm}$.

A terceira variante ( 4 fragmentos - $4 \mathrm{NMI}$ ) engloba vasos com colo mais estreito, mas igualmente longo, e bordo simples, oblíquo e exvertido (11627, 23617). Um destes recipientes apresenta um engobe violáceo na superfície externa. Os seus diâmetros de bordo oscilam entre os 120 e os $150 \mathrm{~mm}$.

Uma quarta variante (2 fragmentos - $2 \mathrm{NMI}$ ) (12133, 11403) mantém os bordos simples, aplanados e de tendência exvertida, que exibem uma pequena depressão na parte superior. Apesar da escassa dimensão dos fragmentos, o colo parece ser largo e consideravelmente longo. Os diâmetros de bordo variam entre os 166 e os $180 \mathrm{~mm}$.

A quinta variante (4 fragmentos - $4 \mathrm{NMI}$ ) integrada neste grupo engloba vasos altos, de corpo ovalado, com colo longo e relativamente estreito, e bordos exvertidos, simples ou com um ligeiro espessamento, que podem ter uma terminação aguçada ou arredondada (13932, 13719, 21259, 18684). Um destes exemplares, que apresenta um perfil mais completo, exibe duas asas de secção rectangular que arrancam do bordo. Os seus diâmetros de bordo oscilam entre os 84 e os $120 \mathrm{~mm}$. Considerando o seu colo, que é bastante alto, não é improvável que estes recipientes se pudessem destinar principalmente ao armazenamento de líquidos, sendo assim possível equacionar uma provável função também no serviço de mesa.

Outro tipo de recipientes (3 fragmentos - 3 NMI) caracteriza-se por possuir colos curtos e bastante estrangulados $(23160,12335)$. Os bordos, exvertidos, exibem uma secção triangular. Um dos exemplares tem aplicado, na superfície externa, uma banda pintada de cor vermelha. Os diâmetros de bordo variam entre os 96 e os $132 \mathrm{~mm}$. 

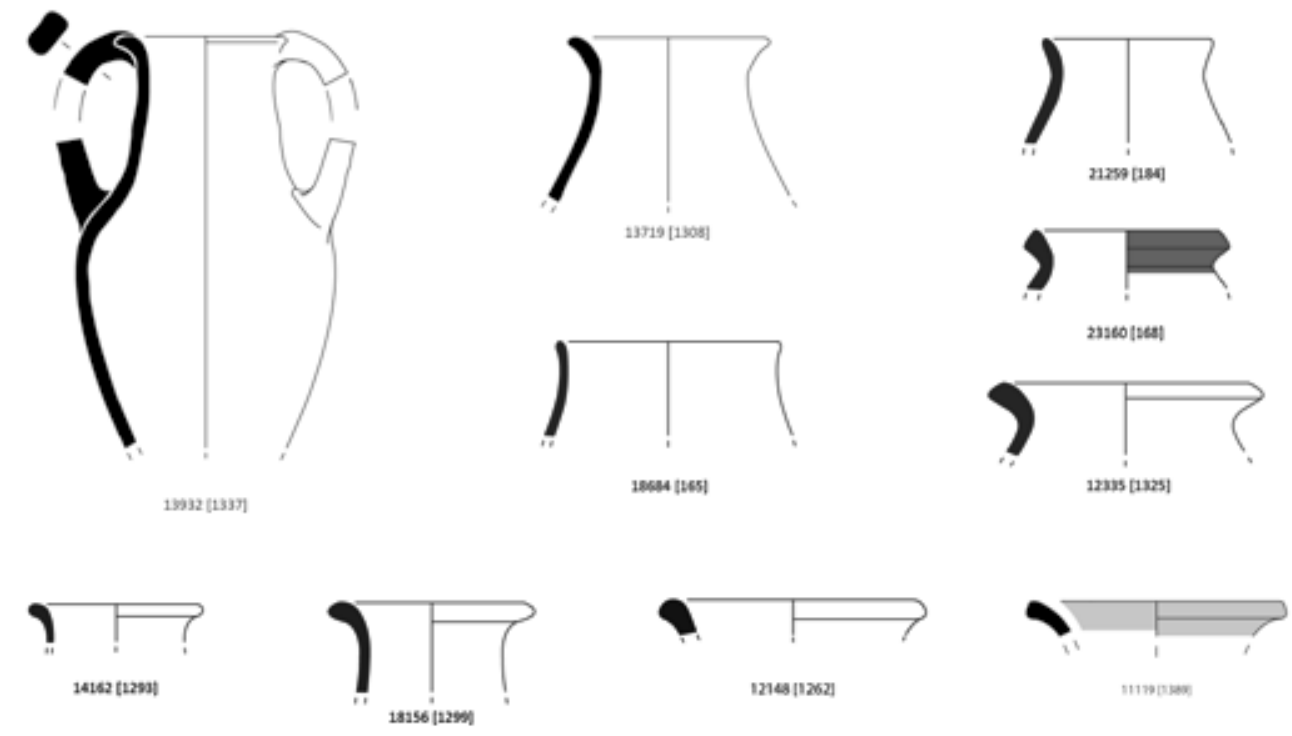

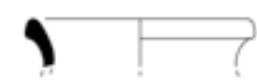

123412262
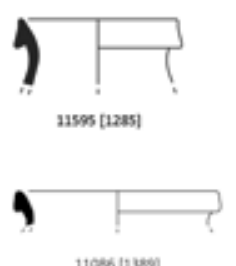

11066 [1285)

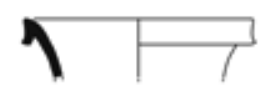

22346 [1265!

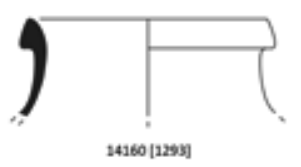

14160 [1258]

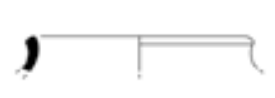

$13624[3008]$

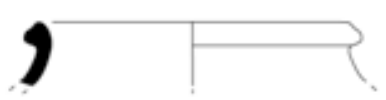

13622 [1306)

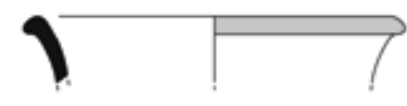

12144 [1262)

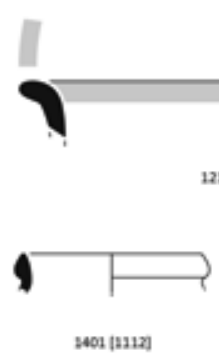

2401 [1123]
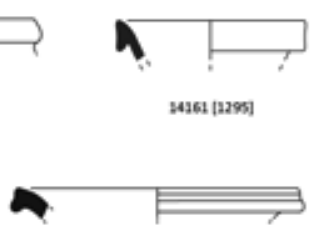

1264s |1262!

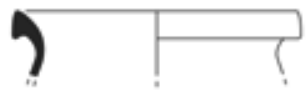

24200 [3291]

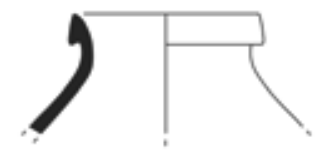

11594 [1286]

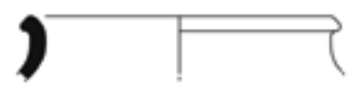

1000 และมี

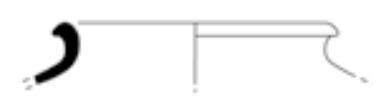

12735 [1323]

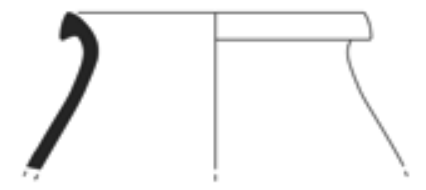

2งแม [19:

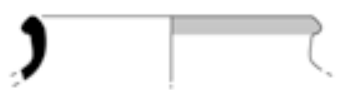

1275s [132]]

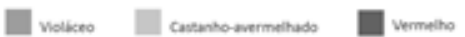

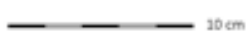

Figura 5. Produções da baía de Cádis (potes e/ou panelas). 
Outros vasos (11 fragmentos - $11 \mathrm{NMI}$ ) de colo longo, exibem um bordo exvertido, mais ou menos prolongado, de terminação espessada e arredondada, bem assinalada na superfície externa (14162, 18156, 12148, 11119, 12141). Alguns destes exemplares apresentam uma pintura castanha-avermelhada na zona externa e, por vezes, também na interna, na área superior. Os diâmetros de bordo oscilam entre os de 87 e os $132 \mathrm{~mm}$.

Exemplares idênticos aos previamente referidos ( 2 fragmentos - $2 \mathrm{NMI}$ ), mas com uma dimensão consideravelmente maior, foram também identificados entre o conjunto $(12144,12142)$. Apresentam bandas pintadas de vermelho e castanho-avermelhado nas superfícies internas e externas e, por vezes, linhas verticais exteriores, que poderiam compor algum tipo de motivos geométricos. Os seus diâmetros de bordo variam entre os de 195 e os 225 $\mathrm{mm}$.

Um segundo grupo morfológico de potes / panelas identificado em Monte Molião incluí exemplares que exibem bordos bem assinalados na superfície externa, que formam lábios pendentes.

A primeira variante deste grupo (34 fragmentos - $34 \mathrm{NMI})$ reúne vasos piriformes, de colo médio-alto, estrangulado, com bordo pendente de formato sub-triangular. Corresponde à forma GDR 8.1.1 (Sáez Romero, 2005), cuja produção parece arrancar no final do século IV a.n.e., prolongandose, pelo menos, durante as duas centúrias seguintes (Bernal Casasola et al, 2003; Sáez Romero, 2005, p. 158). É um dos tipos mais bem representados no conjunto das formas fechadas de produção gaditana $(11595,21248,11285,1401,14161,11086,12147$, 11925, 12145, 12146, 14208, 14639, 14160, 11594, 21311). Os seus diâmetros de bordo oscilam entre os 78 e os $159 \mathrm{~mm}$.

A segunda variante (7 fragmentos - $7 \mathrm{NMI})$ engloba recipientes com um colo largo e curto e bordo bem assinalado na superfície externa, de secção tendencialmente triangular ou sub-arredondada (13624, 1400, 12736, 13622, 12735). Um dos fragmentos apresenta uma banda castanho-avermelhada na zona externa do bordo. Os seus diâmetros de bordo variam entre os de 114 e os $165 \mathrm{~mm}$.

Outra variante, a mais bem representada deste grupo morfo-funcional ( 45 fragmentos - $45 \mathrm{NMI}$ ), inclui vasos de corpo globular ou ovalado, de colo alto e tendencialmente vertical, e bordo pendente, que pode apresentar um formato triangular ou arredondado (12695, 11020, 11284, 11084, 10929,
13749, 12317, 14816, 11019, 12186, 11623, 11407). Num único caso, a separação entre o colo e o corpo da peça está marcada por uma pequena saliência. Corresponde ao tipo GDR 12.3.2., balizado entre o século III e II a.n.e. (Sáez Romero, 2005). Apresentam também, com alguma frequência, bandas de tonalidade vermelha, castanho-avermelhada e violácea pintadas na superfície externa. Os diâmetros de bordo oscilam entre os de 120 e os $165 \mathrm{~mm}$.

Um outro tipo de recipiente $(3$ fragmentos - 3 NMI), de maior dimensão, mantém as características de bordo anteriormente referidas, mas apresenta um colo mais curto e mais largo (12572). Exibe ainda bandas castanho-avermelhadas, pintadas nas superfícies externa e interna. $\mathrm{O}$ diâmetro de bordo do único exemplar que permitiu a representação gráfica é de $243 \mathrm{~mm}$.

Sete exemplares apresentam características singulares, que dificultam a sua integração na repartição previamente efectuada.

O primeiro (1 fragmento - $1 \mathrm{NMI}$ ) parece corresponder a um vaso de colo alto e vertical, com um pequeno bordo pendente colado à restante parede da peça (1403). O diâmetro de bordo é de $84 \mathrm{~mm}$.

Outros três fragmentos (3 NMI) apresentam um bordo exvertido, com a terminação reentrante e aplanada, formando um pequeno sulco interno (14422). O diâmetro de bordo do único exemplar que permitiu uma representação gráfica é de $141 \mathrm{~mm}$.

\subsection{Grandes recipientes tipo dolia}

Recipientes de grandes dimensões foram também identificados entre o conjunto de cerâmica comum gaditana do Monte Molião (3 fragmentos - 3 NMI). Caracterizam-se por apresentar colos curtos e bordos exvertidos, que chegam a formar um lábio pendente, de secção tendencialmente triangular (12143, 12139, 21247). Os seus diâmetros de bordo, muito amplos, variam entre os 312 e os $360 \mathrm{~mm}$.

A funcionalidade primária deste tipo de vasos seria o armazenamento de alimentos.

\subsection{Jarrinhas}

Um dos últimos tipos formais de produção gaditana registado em Monte Molião corresponde a jarras (13 NMI) integráveis, genericamente, no tipo GDR 10 (Sáez Romero, 2005). Infelizmente, o elevado grau de fragmentação do conjunto condicionou, na maioria dos casos, uma classificação mais específica.

Em linhas gerais, são recipientes com diâmetros de bordo diminutos (variam entre os 39 e os 99 $\mathrm{mm}$ ), colo alto e estreito, com bordos tendencial- 
mente simples. Podem apresentar asas com secções ovais, com presença de sulcos, mais ou menos profundos, na sua parte externa $(11396,11939,10858$, 11397, 23618, 6593, 10857, 11402, 14840).

A presença de uma asa sobre-elevada em um dos exemplares (11939) permitiu integrá-lo na variante GDR 10.1.1 de Sáez Romero (2005), balizada entre meados do século III a.n.e. e os inícios da centúria seguinte. Outro fragmento (11397) com asa de secção oval e aplanada, poderia enquadrar-se na variante 10.2.1, datada entre meados do século III e meados do século II a.n.e. (Sáez Romero, 2005, p. 161). Os restantes exemplares não foram passíveis de serem integrados nas variantes estabelecidas para as produções gaditanas.

Resta apenas referir que um único (14840) exibe a presença de decoração pintada, de tonalidade castanho-avermelhada, na superfície externa e na interna, junto ao bordo.

\subsection{Unguentários}

Apesar de escassos, registaram-se alguns fragmentos atribuíveis a partes de unguentários, concretamente gargalos, paredes e pés maciços (10 fragmentos - $6 \mathrm{NMI})$. Destes, apenas um possibilitou a representação gráfica (24236), correspondendo a um vaso de corpo ovalado, gargalo longo e estreito, e um arranque de fundo maciço.

\subsection{Fragmentos inclassificáveis}

Entre os fragmentos de produção da baía de Cádis, contabilizaram-se muitos que não permitiram uma classificação concreta.

É o caso dos fundos, que, muitas vezes, não possibilitam uma integração tipológica. Entre estes, 178 fragmentos apresentam um fundo plano ou ligeiramente convexo e um pé invariavelmente destacado, correspondendo provavelmente às bases das tigelas tipo GDR 1.2., a julgar também pela frequência desta forma nos níveis romano-republicanos de Monte Molião. Outros 13 têm fundo em ônfalo e poderão pertencer aos vasos do tipo GDR 8.1.1 ou às jarras tipo GDR 10.1.1. Fundos de pé anelar também estão presentes entre o conjunto, com 22 fragmentos, sendo, contudo, difícil relacioná-los com formas específicas. Outros 59 fragmentos exibem fundos planos ou convexos que podem pertencer a diversos tipos formais.

Somam-se ainda 53 fragmentos de asa, que possuem secções variáveis, concretamente em fita, e ainda de secção circular ou ovalada. Apesar de ser provável a sua correspondência com os recipientes de tipo jarra, não se deve excluir a possibilidade de pertencerem a outros tipos de formas fechadas. Registam-se ainda vários fragmentos de paredes e carenas (127 fragmentos) que, por vezes, apresentam vestígios de aplicação de bandas, engobes ou aguadas, em tons vermelhos, violáceos, castanhos e acinzentados, perfurações e outros tipos de marcas.

Por último, deve referir-se a presença de 36 fragmentos de bordo (36 NMI) que, dado o seu estado de conservação, não permitiram uma classificação tipológica precisa.

\subsection{Discussão}

As produções da baía gaditana constituem, sem dúvida, o conjunto de cerâmica comum mais expressivo da fase romano-republicana de Monte Molião $(63,38 \%)$. Tal realidade deve ser entendida não só pela proximidade entre esta área de produção e o sítio algarvio, mas também pela posição de destaque que a própria metrópole gaditana adquire, pelo menos, desde a segunda metade do $1^{0}$ milénio a.n.e., nos circuitos comerciais do Extremo Ocidente.

Quando observamos a distribuição dos diversos tipos morfo-funcionais identificados entre a cerâmica comum de origem gaditana recuperada nas escavações de Monte Molião, observa-se um claro domínio das tigelas $(68,57 \%)$. Como já foi observado anteriormente, esta tendência parece revelar uma clara continuidade com os padrões da fase final da Idade do Ferro, verificada não só em Monte Molião, mas também em outros povoados da costa algarvia, como é o caso de Faro ou do Castelo de Castro Marim (Sousa, 2009; Sousa e Arruda, 2011). O sucesso desta forma poderá relacionar-se com um seu eventual carácter multi-funcional, que englobaria não só o serviço de mesa e a preparação/confecção de alimentos, mas também a sua utilização enquanto tampa.

As outras formas abertas, concretamente as pequenas e grandes taças $(2,34 \% ; 1,12 \%)$, almofarizes $(0,71 \%)$, bacias/alguidares $(1,63 \%)$ e pratos $(2,54 \%)$, relacionados também com o serviço de mesa, preparação/confecção de alimentos, armazenamento e eventualmente, com a higiene pessoal, são menos expressivas em termos numéricos. Os exemplares utilizados como tampas têm também uma representação discreta neste conjunto $(3,15 \%)$, apesar de outros tipos de vasos poderem ter desempenhado uma função semelhante.

Entre as formas fechadas, os recipientes designados por pote/panela são os mais numerosos $(14,14 \%)$, sendo muito provavelmente utilizados sobretudo no serviço de mesa e no armazenamento de alimentos, dadas as suas limitações na exposi- 


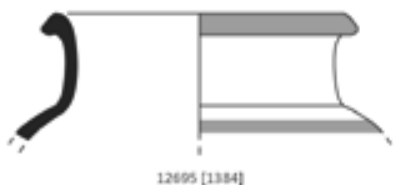

12005 [13e4]
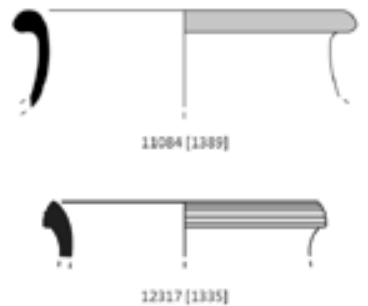

12327 [12)

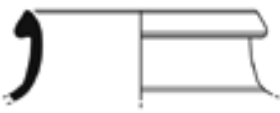

12186 [126]

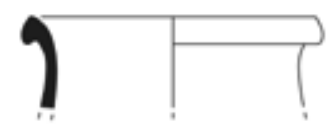

12000 [1281]

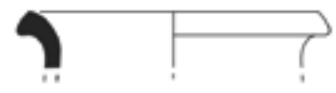

20929 [1260]

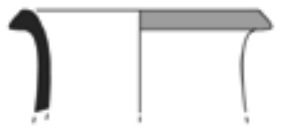

14816 [1309]
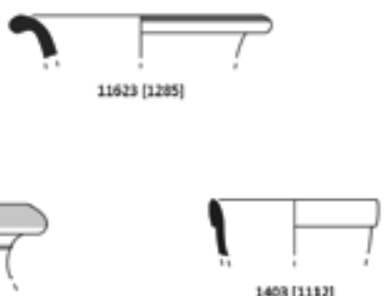

1403 [1112]

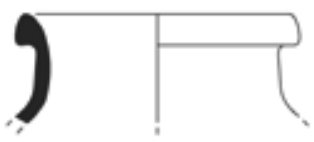

$11284[127)$

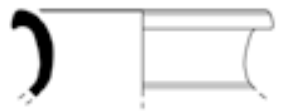

13749[1308]

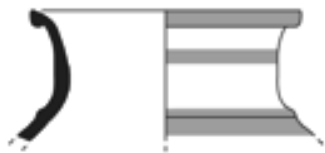

19019 [12:1]
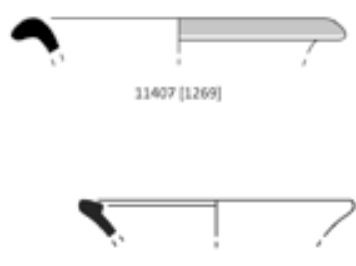

$14422[1266)$

125n[1318]
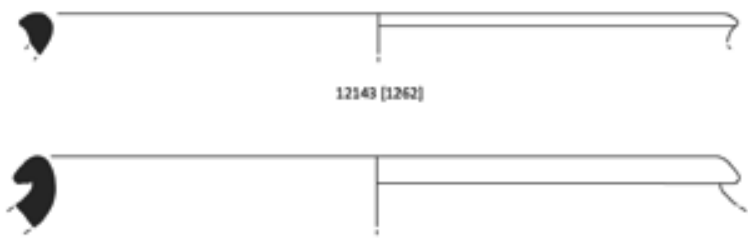

1210 [12ง
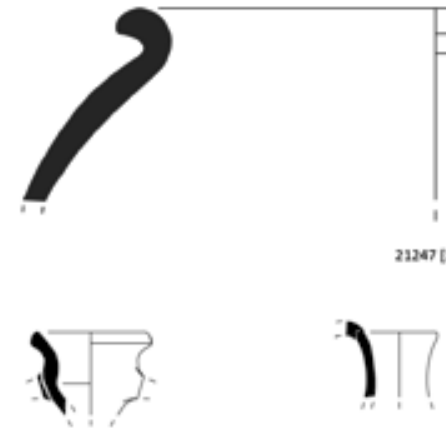

$11396[1269]$

11939 [1296]
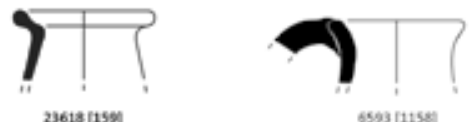

o593 [1158)

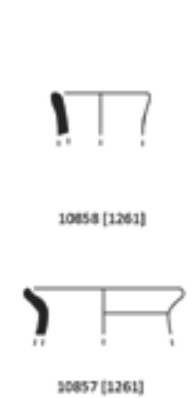

10ess [1261]

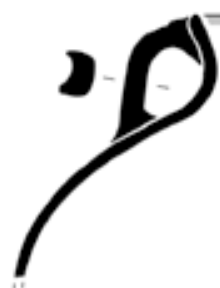

2450 [1 [1ะ9]
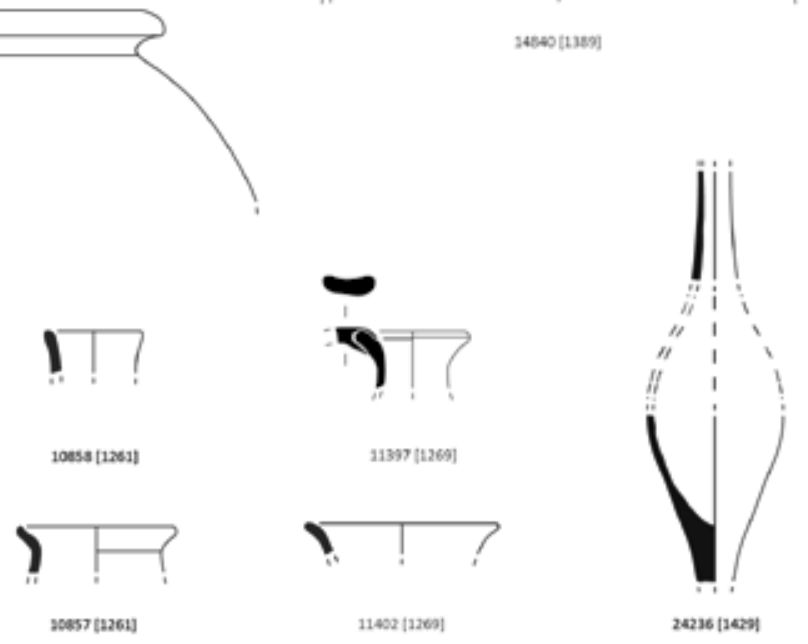

volkseo

vermene

Figura 6. Produções da baía de Cádis (potes e/ou panelas, jarrinhas, unguentário). 
ção ao fogo. Cabe assinalar a considerável variedade morfológica entre estes vasos, que têm formas bem conhecidas na área gaditana, apresentando contudo algumas peculiaridades que permitem a distinção de novas variantes, que deverão ser acrescentadas à seriação tipológica proposta para a cerâmica comum gaditana. Por outro lado, é importante referir a presença de recipientes de grandes dimensões, de tipo dolia $(0,31 \%)$, cuja ocorrência em contextos republicanos do Extremo Ocidente é ainda mal conhecida. As jarras (1,32\%), destinadas quase exclusivamente ao serviço de mesa, e os unguentários $(0,51 \%)$ encerram o repertório formal das produções da baía de Cádis em Monte Molião, sendo de acrescentar apenas os exemplares que não permitiram uma aproximação tipológica $(3,66 \%)$.

\section{Produções da ÁREA do Guadalquivir A}

Este grupo de fabrico engloba as produções mais típicas do vale do Guadalquivir de época romano-republicana (68 fragmentos - $43 \mathrm{NMI}$ ), sendo a sua representatividade no conjunto pouco significativa, $2,77 \%$. As pastas, cujas tonalidades variam entre o bege esbranquiçado e o amarelo-claro, apresentam uma quantidade bastante significativa de elementos não plásticos, de formato geralmente sub-arredondado, sendo semelhantes às dos contentores anfóricos que, anos mais tarde, são produzidos na mesma zona (Haltern 70, LC 67, Dressel 20, etc.).

Infelizmente, a cerâmica comum fabricada na área não dispõe, até ao momento, de estudos tipológicos que permitam definir o elenco de formas produzidas durante a fase coeva à da ocupação republicana de Monte Molião.

Os exemplares recolhidos nos contextos de cronologia republicana do sítio algarvio que se integram nesta produção apresentam uma variedade formal bastante reduzida.

\subsection{Tigelas}

Reconheceram-se escassos fragmentos (2 fragmentos - $2 \mathrm{NMI}$ ) que pertencem a tigelas, de perfil idêntico ao tipo GDR 1.2.1 estabelecido para as produções da baía gaditana (Sáez Romero, 2005). Infelizmente, o seu estado de fragmentação não possibilitou a representação gráfica de nenhum dos exemplares.

\subsection{Grandes taças}

As grandes taças estão também presentes (3 fragmentos - $3 \mathrm{NMI}$ ), apresentando um corpo semi-hesmisférico e um bordo exvertido, aplanado e bastante espessado $(6435,6436,6434)$. Os diâmetros de bordo oscilam entre os de 249 e os $261 \mathrm{~mm}$.

\subsection{Almofarizes}

Os almofarizes fazem também parte do repertório desta produção, apesar de estarem escassamente representados (3 fragmentos - 2 NMI). Registaram-se apenas fragmentos de fundo, de pé anelar, com incrustações na superfície interna que permitiam um melhor atrito (11006). O único exemplar que permitiu uma representação gráfica tem um diâmetro de fundo de $216 \mathrm{~mm}$.

\subsection{Bacias e/ou alguidares}

A forma mais bem representada no conjunto de cerâmica comum desta área corresponde aos recipientes tipo bacia e/ou alguidar, sendo possível distinguir três variantes.

A primeira engloba vasos de perfil carenado $(8$ fragmentos - $8 \mathrm{NMI}$ ). Os bordos são consideravelmente espessados, de tendência exvertida e secção ovalada (14421, 10906) ou sub-triangular (13941, 11942). Os diâmetros de bordo variam entre os de 354 e os $600 \mathrm{~mm}$.

A segunda variante ( 3 fragmentos $-3 \mathrm{NMI})$ corresponde a vasos de perfil mais hemisférico, com paredes tendencialmente mais rectas, e bordo exvertido, espessado e de secção arredondada (11203, 10907). Os diâmetros de bordo oscilam entre os de 498 e os $531 \mathrm{~mm}$.

A última variante inclui vasos de paredes oblíquas ( 5 fragmentos - $5 \mathrm{NMI}$ ). Os bordos são exvertidos e espessados, de secção arredondada (12761) ou ovalada $(18689,10884)$, podendo, neste último caso, apresentar um perfil moldurado (11398, 13692). Os diâmetros de bordo variam entre os de 255 e os $390 \mathrm{~mm}$.

Cabe ainda referir a existência de quatro fragmentos de bordo (4 NMI) que, apesar de corresponderem seguramente a recipientes tipo bacia / alguidar, não permitiram, dado o seu estado de conservação, uma descrição mais específica.

\subsection{Tampas}

As tampas, sendo pouco representativas em termos quantitativos, apresentam características que permitiram uma subdivisão em duas variantes.

A primeira, representada singularmente (1 NMI), caracteriza-se por um perfil claramente horizontal, bordo recto e vertical (12375). O diâmetro de bordo é reduzido, $87 \mathrm{~mm}$.

A segunda variante (2 NMI) engloba perfis idênticos aos anteriormente registados para as produções da baía gaditana, com bordo aplanado e parede convexa (10903). O diâmetro de bordo do único 

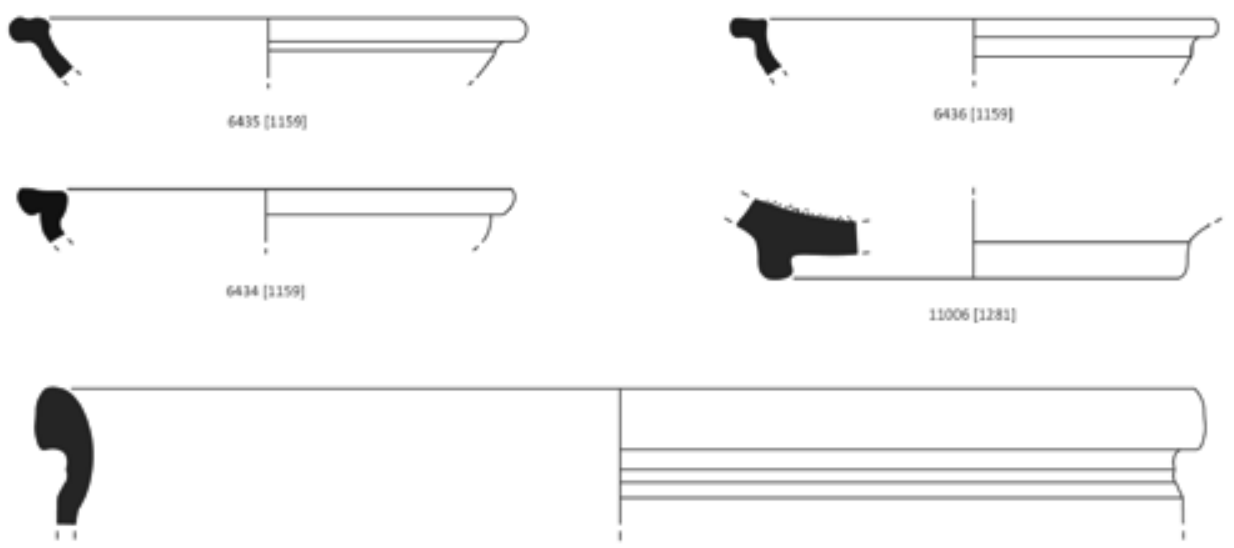

13941 (1326)
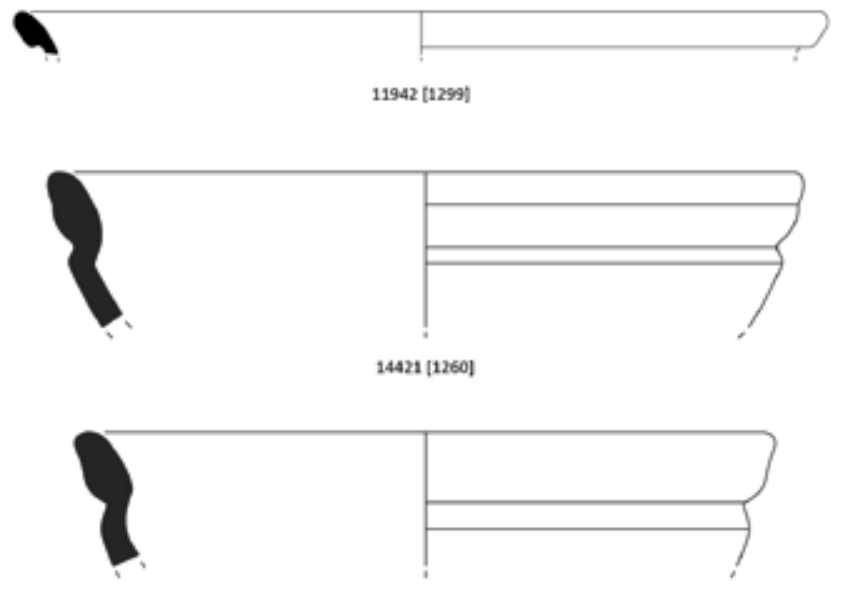

10906 [1260]
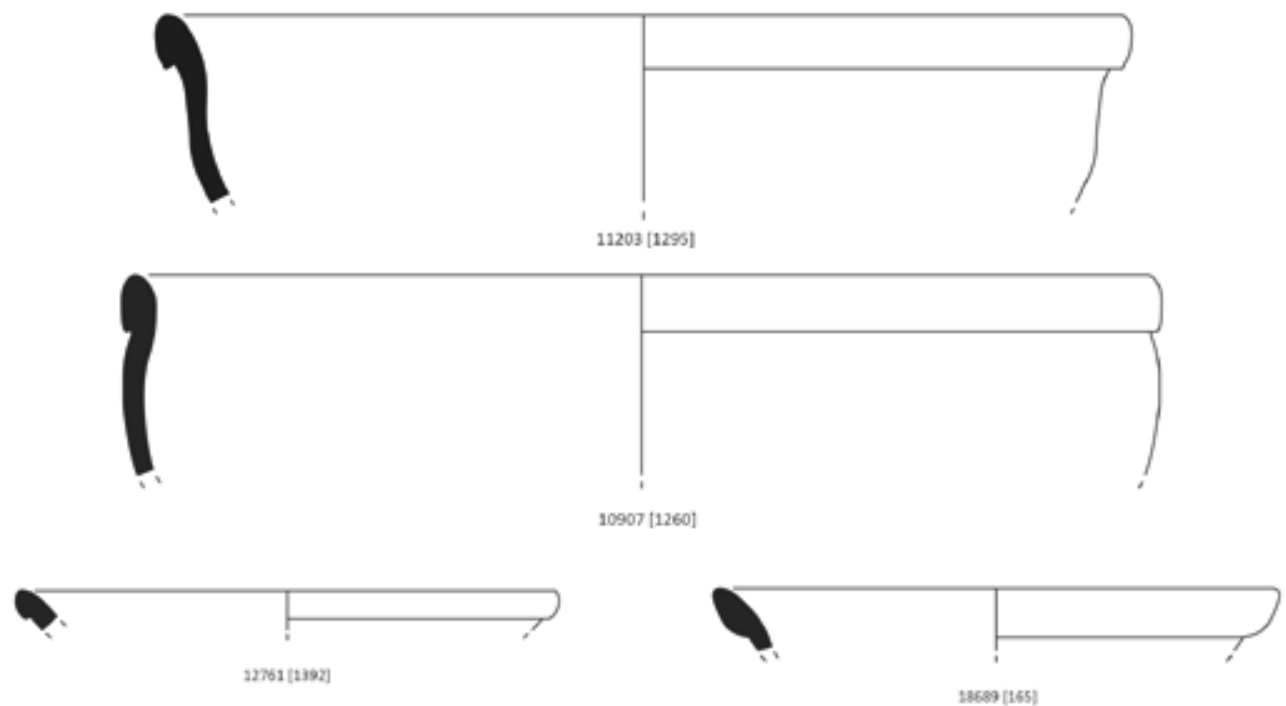

28689 [165]

Figura 7. Produções Guadalquivir A (grandes taças, almofariz e bacias/alguidares). 
exemplar que permitiu uma representação gráfica é de $276 \mathrm{~mm}$.

\subsection{Potes e/ou panelas}

Entre os potes/panelas, também raros, distinguiram-se dois tipos.

O primeiro (1 fragmento - $1 \mathrm{NMI}$ ), de colo baixo, apresenta bordo exvertido e espessado, com secção arredondada (1404), assemelhando-se, em linhas gerais, a formas já documentadas nas produções de Cádis. O diâmetro de bordo é de $126 \mathrm{~mm}$.

O segundo (1 fragmento - $1 \mathrm{NMI}$ ) tem um colo mais alto do que o anterior e tendencialmente vertical, com bordo pendente e sub-circular (13907), semelhante também a uma das variantes já registadas para a baía de Cádis. $\mathrm{O}$ diâmetro de bordo é de $240 \mathrm{~mm}$.

\subsection{Grandes recipientes tipo dolia}

$\mathrm{O}$ último tipo morfo-funcional identificado neste grupo de fabrico engloba recipientes de grande dimensão, tipo dolia ( 2 fragmentos - $2 \mathrm{NMI}$ ). O bordo é exvertido e o colo é curto (12170). Também neste caso, é possível registar grandes semelhanças morfológicas com os tipos fabricados na área gaditana. O diâmetro de bordo do único exemplar que permitiu uma representação gráfica é de $354 \mathrm{~mm}$.

\subsection{Fragmentos inclassificáveis}

Entre os materiais provenientes da bacia do Guadalquivir, registam-se vários exemplares que não possibilitaram uma aproximação tipológica mais específica.

Trata-se de dois fragmentos de parede e 18 fundos (2 NMI). Entre estes últimos, dois, pela amplitude do seu diâmetro, corresponderão a grandes recipientes. Um outro exibe um pé anular, dois têm fundos planos com pé destacado, podendo pertencer a tigelas, e outros 13 integram fundos planos e convexos, não sendo possível adivinhar a forma original.

As asas estão representados por seis exemplares, que exibem secções circulares e, com maior frequência, ovaladas.

Os elementos de bordos que não permitiram uma classifıcação em grupos morfo-funcionais totalizam sete exemplares (7 NMI).

\subsection{Discussão}

Os vasos provenientes da bacia do Guadalquivir são, em termos numéricos, pouco expressivos, somando apenas $2,77 \%$. Deve, no entanto, ter-se em consideração a cronologia dos contextos estudados, que se centra entre finais do séc. II e inícios do séc. I a.n.e., que parece corresponder a uma fase aparentemente embrionária no quadro das produções do in- terior da Andaluzia. Com efeito, o factor que parece desencadear o momento áureo destes centros produtores relaciona-se com a produção de contentores anfóricos, que só aparecem no registo arqueológico do território actualmente português já em finais do $1^{0}$ quartel do séc. I a.n.e. No entanto, a estratigrafia registada no Monte Molião parece indicar que os contactos com essa área se iniciam em momentos anteriores, apesar de se materializarem apenas na importação de recipientes de cerâmica comum.

A análise da distribuição morfológica destas produções revela uma notável predominância de formas abertas e amplas, entre as quais se contam os vasos tipo bacia/alguidar $(46,51 \%)$, grandes taças $(6,98 \% \%)$ e almofarizes $(4,65 \%)$, que seriam utilizados sobretudo na preparação de alimentos e no armazenamento, não sendo de descurar a possibilidade de alguns destes recipientes serem usados em tarefas ligadas à higiene pessoal. Vasos mais pequenos, como é o caso das tigelas $(4,65 \%)$, dos potes/ panelas $(4,65 \%)$ e mesmo das tampas $(6,98 \%)$, são raros. Deve ainda destacar-se a presença de recipientes de grande dimensão, de tipo dolia $(4,65 \%)$. Os materiais que não permitiram um enquadramento tipológico $(20,93 \%)$ completam este conjunto.

\section{PRoduçõEs da ÁREa do Guadalquivir B}

Entre o conjunto da cerâmica comum do Monte Molião, foi possível também reconhecer a existência de um outro fabrico, que, considerando não só as características das pastas, mas também as morfologias e os motivos decorativos, julgamos estar relacionado com as áreas ditas turdetanas do vale do Guadalquivir (182 fragmentos - 92 NMI). Correspondem a 5,93\% do conjunto. As pastas apresentam uma textura compacta, com tonalidades claras, que oscilam entre o amarelo claro e o amarelo alaranjado, e são, geralmente, pouco depuradas, com elementos não plásticos de média dimensão, sub-angulosos e, mais frequentemente, sub-arredondados. Apresentam, com bastante frequência, a aplicação de bandas pintadas nas suas superfícies, cujas tonalidades variam, sobretudo, entre o vermelho, o vermelho-acastanhado o violáceo.

\subsection{Tigelas}

As tigelas correspondem ao segundo tipo morfo-funcional mais bem representado no quadro destas produções.

Entre o elenco tipológico deste grupo, regista-se as tigelas de perfil hemisférico (12 fragmentos -12 NMI), que são morfologicamente idênticas ao tipo 


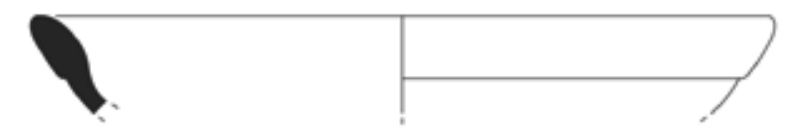

10084 [1261]
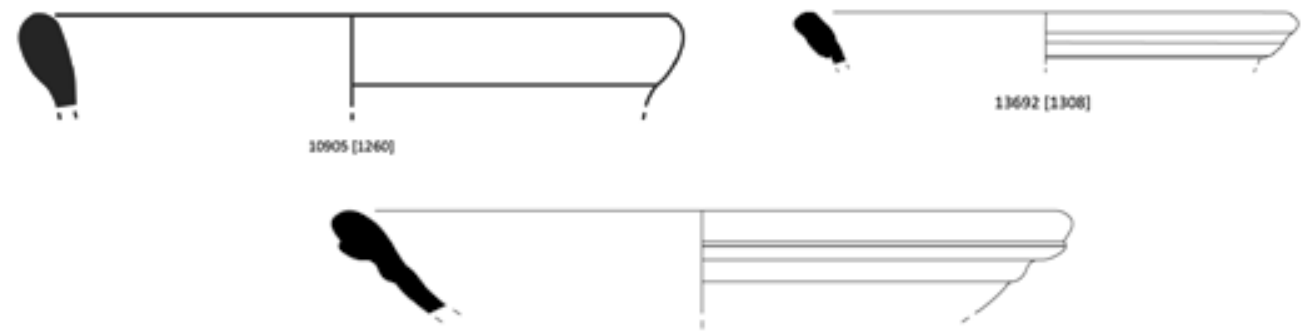

1112ง [126ต]

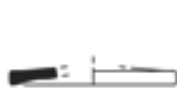

12.มว โ1ม2ง|

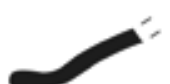

4

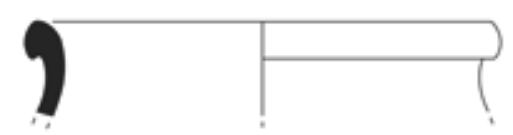

11000 [11m
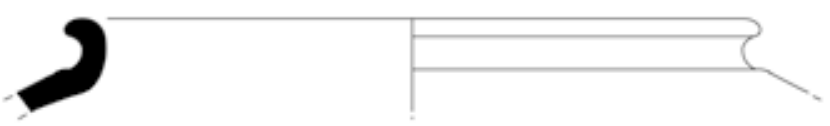

22170 [126ม
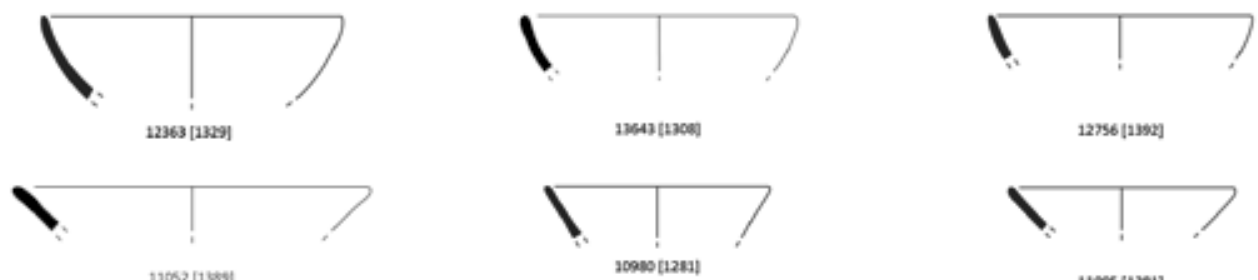

11005 [12*1]
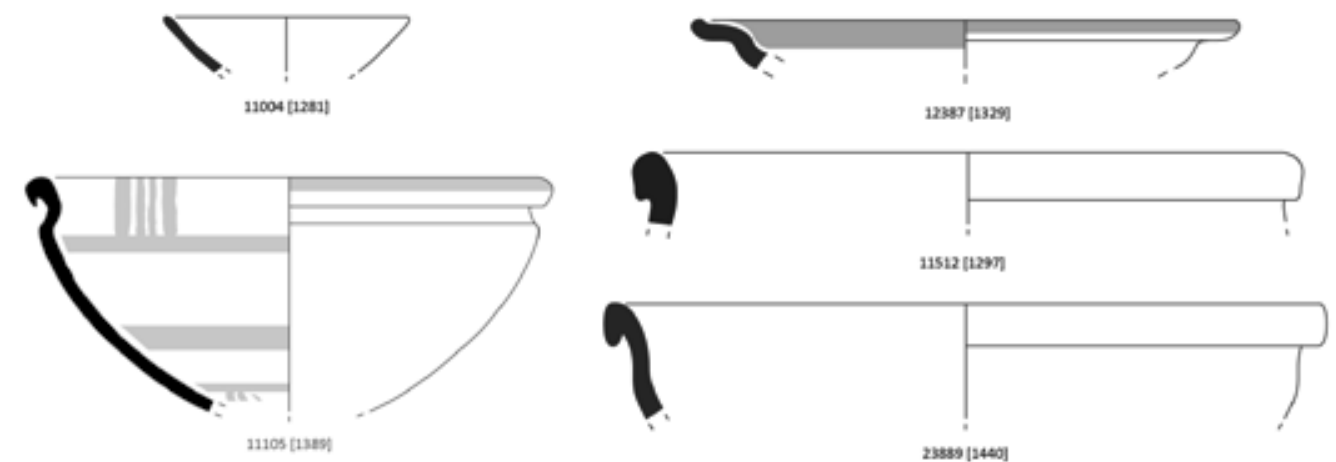

Volkces Cutanko-wermethedo

Figura 8. Produções Guadalquivir A (bacias/alguidares, tampas, potes/panelas e grande recipiente tipo dolia); Produções Guadalquivir B (tigelas, prato e bacias/alguidares). 
GDR 1.2.1 (Sáez Romero, 2005), não mostrando, contudo, qualquer engrossamento ao nível do bordo $(12363,13643)$. Os diâmetros variam entre os 144 e os $159 \mathrm{~mm}$.

Um exemplar similar ao tipo GDR 1.2.2 (1 NMI), com bordo apontado (12756), foi também identificado. O diâmetro de bordo é de $138 \mathrm{~mm}$.

Identificou-se ainda um outro conjunto de tigelas ( 4 fragmentos - $4 \mathrm{NMI}$ ), que encontra também uma clara correspondência com os tipos gaditanos, concretamente com a forma GDR 1.2.3, de paredes rectas e oblíquas $(11052,11005,10980,11004)$. Os diâmetros de bordo variam entre os 117 e os 186 $\mathrm{mm}$.

\subsection{Pequenas taças}

Entre este conjunto, identificaram-se dois exemplares ( 2 fragmentos - $2 \mathrm{NMI}$ ) que correspondem a pequenas taças de bordo reentrante equivalente ao tipo GDR 1.1.2 (Sáez Romero, 2005). Infelizmente, nenhum deles permitiu uma reconstituição gráfica.

5.3. Pratos

Um único vaso apresenta características que permitem a sua integração nesta categoria morfofuncional.

Este fragmento (1 NMI) tem um bordo relativamente aplanado, de secção arredondada, a partir da qual se desenvolvem as paredes, de tendência côncava (12387). Exibe pintura violácea na superfície interna e externa, neste caso sobre o bordo. O diâmetro de bordo é de $285 \mathrm{~mm}$.

Existem algumas semelhanças entre este exemplar e alguns tipos de pratos da cerâmica campaniense, concretamente a forma 6 de Lamboglia, não sendo impossível pensar numa eventual influência da cerâmica de mesa itálica nas produções desta área geográfica.

\subsection{Bacias e/ou alguidares}

Os recipientes de tipo bacia e/ou alguidar constituem um dos grupos mais bem representados nesta produção.

Mais uma vez, estão presentes os vasos de perfil carenado ( 4 fragmentos - $4 \mathrm{NMI}$ ), com bordo espessado de secção ovalada ou sub-circular (11105, 11512), similares aos do tipo GDR 4.1.1 (Sáez Romero, 2005), decorados, por vezes, com bandas de tonalidade castanha-avermelhada. Os diâmetros de bordo oscilam entre os 264 e os $336 \mathrm{~mm}$.

Outros exibem um perfil mais hemisférico ( 7 fragmentos - $6 \mathrm{NMI})$ e, num dos casos, paredes mais oblíquas (23889). Os bordos são exvertidos, arredondados (23319) e, por vezes, pendentes (21233).
Um destes vasos apresenta ainda bandas vermelhas pintadas na sua superfície externa. Os diâmetros de bordo variam entre os 252 e os $378 \mathrm{~mm}$.

\subsection{Potes e/ou panelas}

Os vasos de tipo pote e/ou panela correspondem à forma mais expressiva, em termos quantitativos, desta produção.

Uma das variantes (7 fragmentos - $7 \mathrm{NMI}$ ) engloba vasos de perfil globular, com bordo simples e de tendência vertical, com secção arredondada, muito similares aos já descritos para as produções da baía gaditana $(18153,18803,18154,13668)$. Apresentam, com frequência, pinturas de tonalidade vermelha, violácea ou castanha-avermelhada na superfície externa e interna, junto ao bordo. Os diâmetros variam entre os 129 e os $201 \mathrm{~mm}$.

Outra variante ( 5 fragmentos - $5 \mathrm{NMI}$ ), também reconhecida entre as produções gaditanas, engloba o mesmo tipo de bordos simples de secção arredondada, mas com uma orientação exvertida (13667, 11104). Os diâmetros de bordo variam ente os 114 e os $120 \mathrm{~mm}$. Um destes vasos apresenta um perfil completo, tendo uma altura de $138 \mathrm{~mm}$ e um fundo de pé anelar, com $60 \mathrm{~mm}$ de diâmetro. Estes recipientes apresentam também decorações pintadas em bandas na superfície externa e na interna, junto ao bordo.

Um outro tipo de pote e/ou panela (7 fragmentos - 7 NMI) apresenta um colo pouco desenvolvido, bordo exvertido e aplanado, de secção arredondada (19102, 23870). Exibe bandas pintadas de tonalidade avermelhada na superfície externa. Os dois exemplares que permitiram uma representação gráfica são de dimensões bastante diferentes, tendo o de menor tamanho $153 \mathrm{~mm}$ de diâmetro e o outro $255 \mathrm{~mm}$.

A quarta variante (21 fragmentos - $21 \mathrm{NMI}$ ) integra vasos com lábio pendente, de formato triangular ou arredondado, colo alto e de tendência vertical e corpo globular ou ovalado (13947, 18151, 12393, 11542, 12392, 18152), bastante similares ao tipo GDR 12.3.2 (Sáez Romero, 2005). Apresentam, com grande frequência, bandas vermelhas, violáceas e castanho-avermelhadas na superfície externa. Os diâmetros de bordo variam entre os de 141 e os $234 \mathrm{~mm}$.

Um outro exemplar (1 fragmento - $1 \mathrm{NMI}$ ), idêntico em termos de morfologia à variante previamente descrita, destaca-se pela sua maior dimensão (18389). Apresenta bandas violáceas na superfície externa. O diâmetro de bordo é de $285 \mathrm{~mm}$. 


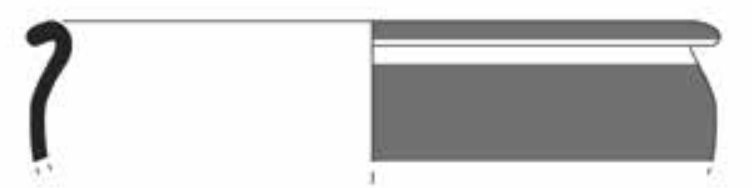

2ma [ase]
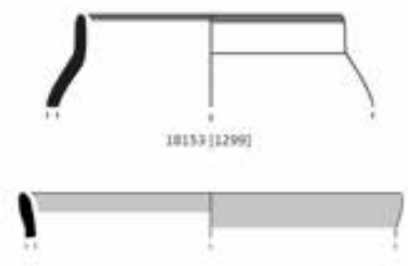

1365: [13:8)
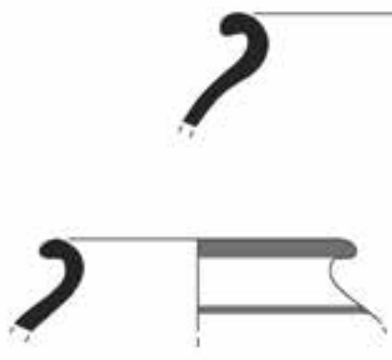

2902 [197]

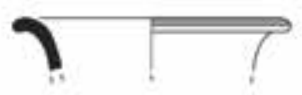

12903 |19อง

23850 t1408)
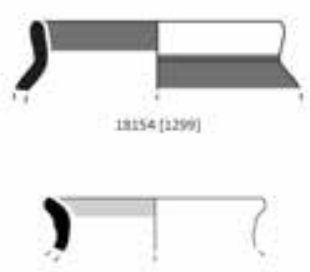

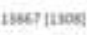

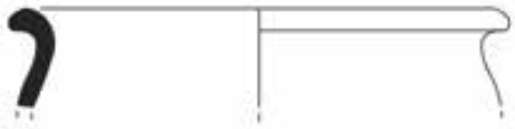

matsta4!
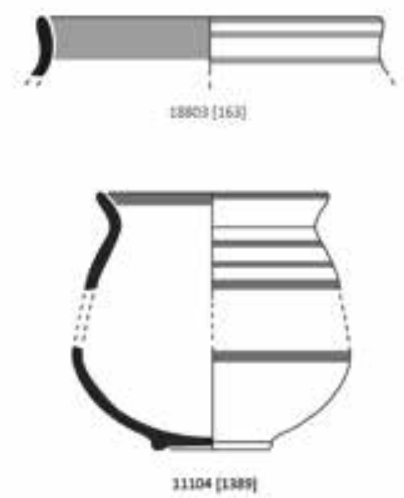

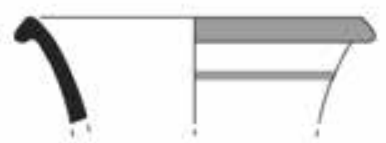

19947 [1396]

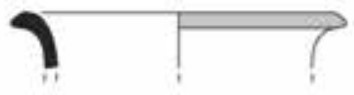

และ [เวต]

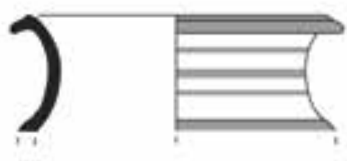

anst (129)!

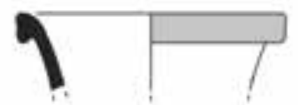

12392 [1389]

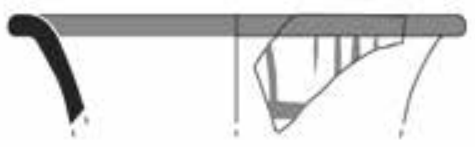

ติ2

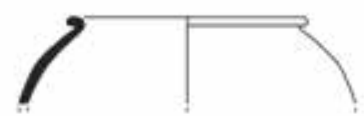

242as [2413)

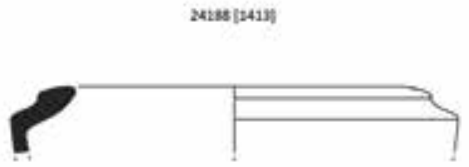

24062 [1414]

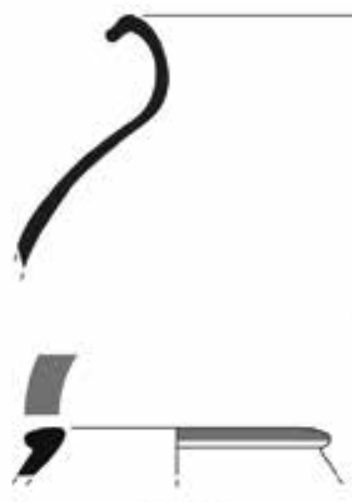

1210) [126)
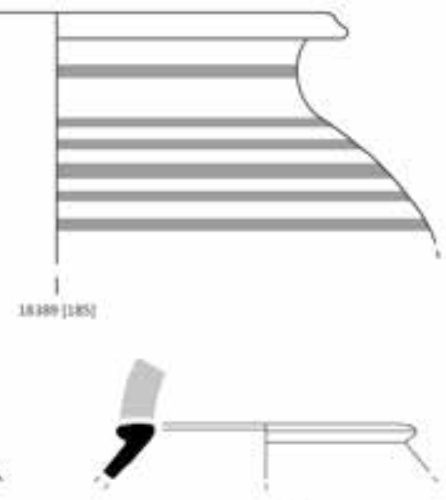

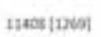
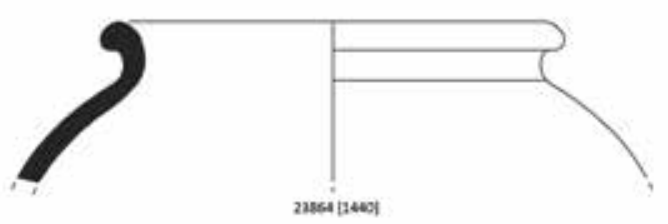

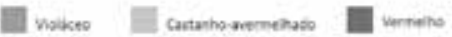

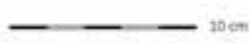

Figura 9. Produções Guadalquivir B (bacias/alguidares e potes/panelas); Produções da Campiña Gaditana (grande recipiente tipo dolia). 
Vasos de colo muito curto, estrangulado e bordo pequeno, exvertido e aplanado foram também documentados no conjunto (1 fragmento - $1 \mathrm{NMI}$ ). $\mathrm{O}$ único exemplar desta variante (24188) tem um diâmetro de bordo de $123 \mathrm{~mm}$.

Destaca-se ainda um outro recipiente (24462), de morfologia invulgar (1 fragmento - $1 \mathrm{NMI}$ ), que exibe um bordo reentrante, de secção aplanada, formando uma carena acentuada na parte superior. Tal como no caso anterior, esta forma está representada singularmente, sendo o diâmetro de bordo de $177 \mathrm{~mm}$.

A última variante enquadrada no tipo pote e/ou panela ( 2 fragmentos $-2 \mathrm{NMI}$ ) caracteriza-se pelos seus bordos exvertidos, engrossados e aplanados, de secção arredondada, colo curto e paredes oblíquas (12187, 11408). Apresenta bandas pintadas com tonalidades avermelhadas e castanho-avermelhadas na superfície externa e sobre o bordo. Os diâmetros de bordo variam entre os 141 e os $234 \mathrm{~mm}$.

\subsection{Jarrinhas}

Entre este grupo, foi possível também identificar um fragmento (1 NMI) que corresponde ao bordo de uma pequena jarra que se assemelha, ao nível morfológico, com o tipo GDR 10 (Sáez Romero, 2005). Infelizmente, o mau estado de conservação da peça não possibilitou a sua representação gráfica.

\subsection{Fragmentos inclassificáveis}

Entre os exemplares que não permitiram um enquadramento tipológico específico destacam-se os fundos. Sete destes fragmentos exibem fundos planos ou ligeiramente convexos, com pé destacado, que podem corresponder às diversas morfologias de tigelas aqui identificadas, e um outro um fundo com pé anelar. Nove têm fundos planos ou convexos e cincos fundos em ônfalo.

Registam-se ainda 63 fragmentos de paredes decoradas com bandas violáceas, vermelho-acastanhadas, vermelhas e cinzentas escuras, e um outro onde ficaram impressas, na parede interna, os negativos de restos carpológicos.

As asas são raras, tendo sido identificados apenas três exemplares. Um deles pertence a uma asa cega e as restantes duas possuem secção circular.

Por fim, deve assinalar-se a presença de 16 bordos (16 NMI) que não permitiram uma classificação tipológica.

\subsection{Discussão}

Este conjunto de produções, que representa $5,93 \%$ do conjunto de cerâmica comum de Monte Molião, apresenta alguma variedade formal, sendo o tipo morfo-funcional mais bem representado o dos potes e/ou panelas $(48,91 \%)$. Seguem-se as tigelas $(18,48 \%)$ e as bacias e/ou alguidares $(10,87 \%)$. Vasos de pequena dimensão são menos expressivos no quadro destas produções, sendo representados pelas pequenas taças $(2,17 \%)$, pratos $(1,09 \%)$ e jarras $(1,09 \%)$. As formas que não permitem um enquadramento tipológico preciso constituem os restantes $17,39 \%$.

Considerando não só o repertório formal deste grupo, que, à excepção do único prato identificado, que poderá evidenciar já influência de protótipos itálicos, se integra no quadro tipológico que remonta à tradição pré-romana, mas também as características decorativas, concretamente a frequência de decorações pintadas, por vezes com motivos reticulados e bandas perpendiculares, é possível associá-lo às produções ditas turdetanas da área do Guadalquivir, que perduram ainda durante a fase romano-republicana.

\section{Produções da Campiña Gaditana}

As pastas de um outro conjunto de peças têm características que permitiram a sua diferenciação dos grupos anteriores. É um grupo pouco expressivo em termos numéricos, representando apenas $0,13 \%$ do conjunto de cerâmica comum.

Trata-se de pastas não calcárias, de textura compacta, pouco depuradas e bicolores, com um núcleo cinzento-escuro e superfícies laranja-acastanhadas. A sua semelhança com as produções pré-romanas do tipo 8.1.1.2 de Ramon Torres (tipo Tiñosa) levanos a propor uma idêntica proveniência, a área da Campiña Gaditana.

\subsection{Grandes recipientes tipo dolia}

Os dois únicos exemplares que se integram nesta produção (2 NMI) correspondem ao mesmo tipo formal. Trata-se de grandes recipientes de tipo dolia, com bordo exvertido e bem assinalado na superfície externa, seguindo-se um colo curto e ligeiramente estrangulado, a partir do qual se desenvolve um corpo aparentemente globular. O único exemplar que possibilitou uma representação gráfica (23864) tem um diâmetro de $228 \mathrm{~mm}$.

\subsection{Discussão}

Apesar da sua escassa expressividade, com apenas $0,13 \%$ do conjunto, a presença destes recipientes poderá relacionar-se com uma eventual continuidade das redes comerciais pré-romanas entre o Algarve e a actual Andaluzia.

Com efeito, a importação de azeite da Campiña Gaditana foi bastante significativa durante o final da 
Idade do Ferro no sul do território português, o que é documentado pela presença, muito expressiva, de contentores anfóricos de azeite do tipo 8.1.1.2. de Ramon Torres (Sousa, 2009; Sousa e Arruda, 2011).

Até ao momento, não é ainda completamente claro se este tipo de ânforas e o seu respectivo produto continuaram a ser comercializadas durante os momentos iniciais do período romano-republicano. A sua presença nos níveis desta cronologia em Monte Molião poderia ser, efectivamente, um indicador dessa pervivência, apesar de ser igualmente provável que correspondam a materiais residuais da fase sidérica (Arruda e Sousa, 2013).

Estes grandes recipientes importados da Campiña Gaditana podem, assim, ser interpretados como vasos de transporte de produtos oleícolas dessa área geográfica, que teriam substituído os contentores anfóricos precedentes, de tipo Tiñosa (8.1.1.2.), ou terem acompanhado estes últimos, contendo um qualquer produto que é, por ora, difícil de determinar.

\section{Produções da fachada oriental da Península} IBÉRICA

Entre o conjunto exumado durante as escavações realizadas no Monte Molião, recolheram-se ainda vários fragmentos de vasos produzidos na costa oriental do território peninsular, no âmbito da zona que tradicionalmente se tem vindo a designar como "área ibérica". Integra pastas compactas e muito bem depuradas, cujas tonalidades variam entre o bege e o laranja claro.

Trata-se de uma produção pouco expressiva no conjunto, com apenas 1,55\% (28 fragmentos - 24 $\mathrm{NMI}$, tendo-se identificado a presença de um único tipo formal.

\subsection{Kalathoi}

Os vasos integrados neste grupo de produção pertencem, exclusivamente, a kalathoi $(28$ fragmentos - $24 \mathrm{NMI}$ ). Correspondem a recipientes com uma capacidade bastante significativa, de corpo cilíndrico, fundo convexo e bordo aplanado. Podem apresentar pinturas de tonalidades violáceas sobre o bordo e superfície externa, que formam diferentes tipos de composições geométricas.

Estes materiais foram recentemente analisados, resultando no seu enquadramento tipológico nos grupos A e B de Conde Berdós (Muccioli, no prelo), que foram produzidos na área catalã (Conde Berdós, 1991). Os diâmetros de bordo variam entre os 153 e os $240 \mathrm{~mm}$.

\subsection{Discussão}

A presença dos vasos de tipo kalathoi em contextos de cronologia romano-republicana é já bem conhecida nos conjuntos artefactuais do Extremo Ocidente. De facto, esta morfologia foi reconhecida em Conimbriga (Alarcão e Etiènne, 1976), Santarém e em Castro Marim (Muccioli, no prelo), apesar de, em nenhum destes sítios, estarem associados a contextos primários de ocupação. Em Lisboa, na Colina do Castelo de São Jorge (Pimenta, 2005) e no Monte Molião (Muccioli, no prelo), foi possível associá-los a outros artefactos que permitiram estabelecer uma cronologia centrada entre o último terço do séc. II e os inícios da centúria seguinte.

Os kalathoi podem ser interpretados como meros contentores de produtos particularmente apreciados, como mel, frutas secas, púrpura, ou mesmo de algum tipo de preparado piscícola (Tarradel e Sanmarti, 1980), e, como tal, seriam o reflexo de circuitos comerciais que teriam atingido o seu auge durante o processo da conquista romana. No entanto, outras linhas de investigação defendem que a difusão destes recipientes, pela sua excepcionalidade em termos formais e decorativos, poderia ter um significado simbólico (Conde Berdós, 1991), não sendo impossível relacioná-la com a movimentação de populações da "área ibérica", como tropas auxiliares, no âmbito das campanhas militares durante o período romano-republicano.

\section{Produções itálicas}

Os recipientes produzidos na Península Itálica não são muito expressivos, em termos quantitativos, representando apenas $2,51 \%$ do conjunto de cerâmica comum, mas apresentam, ainda assim, alguma variedade em termos formais. As pastas destes recipientes são muito características, com texturas medianamente compactas e com tonalidades que variam entre o alaranjado e o avermelhado, distinguindo-se claramente das restantes produções pela presença das características areias negras vulcânicas. Deve ainda acrescentar-se que a superfície externa destes recipientes se encontra, na maior parte dos casos, escurecida, o que evidencia a sua exposição ao fogo.

\subsection{Patinae}

A forma mais bem documentada no conjunto de cerâmica itálica (19 fragmentos - $16 \mathrm{NMI}$ ) corresponde ao pratos (patinae) de paredes altas e arqueadas e fundo plano. O bordo, de secção arredondada, apresenta uma pequena ranhura na sua 


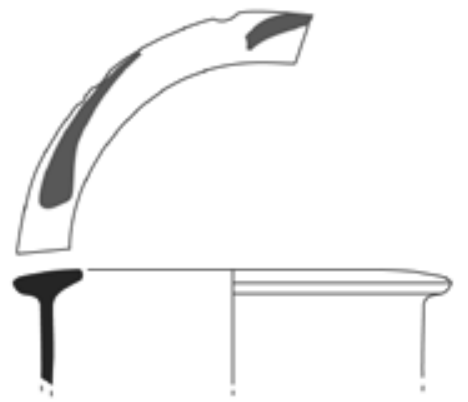

$21260[184]$
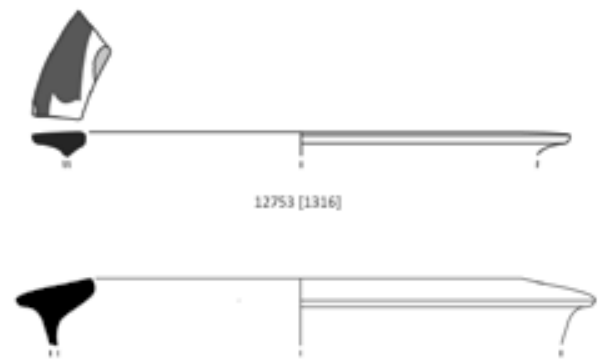

23615 [159]

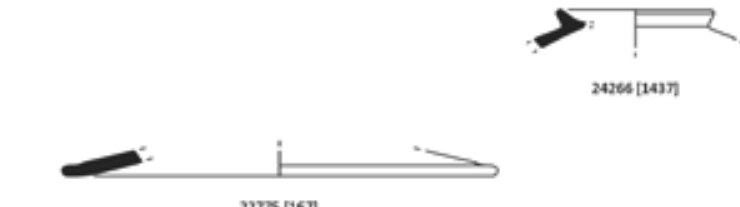

$227 \%$ [16]
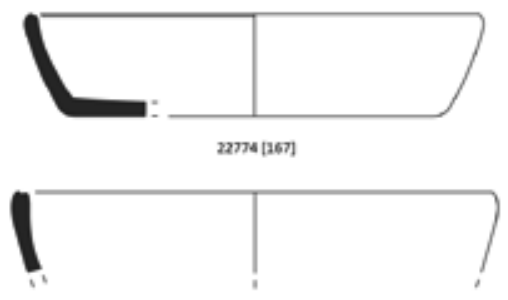

13942 [1325]
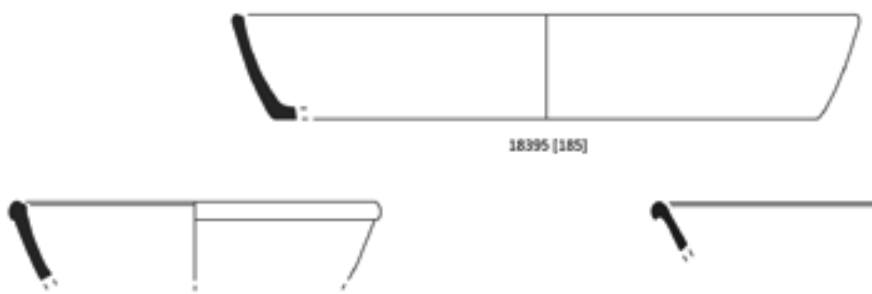

14207 [1292)

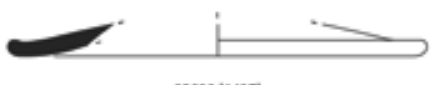

23830 [3437]
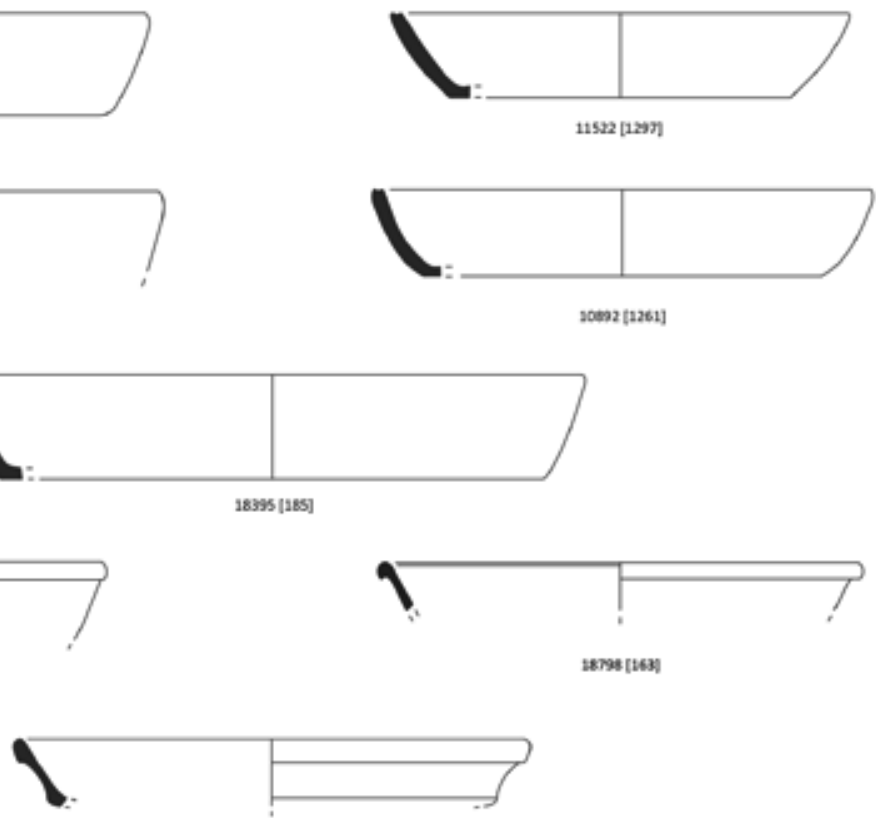

24219 [1429]

| Wolices Cartanho-wermelinado 1 verneho

Figura 10. Produções da zona oriental da Península Ibérica (kalathoi); Produções itálicas (tampas e patinae). 
parte superior, que auxilia na fixação da respectiva tampa (22774, 11522, 13942, 10892, 18395). Estes recipientes integram-se na forma COM-IT $6 \mathrm{c}$ da tipologia de Lattes, cuja cronologia está centrada entre 100 e 50 a.n.e. (Bats, 1993). Os diâmetros de bordo variam entre os 237 e os $324 \mathrm{~mm}$, e os fundos oscilam entre os 180 e os $285 \mathrm{~mm}$.

Um outro tipo de patina (1 fragmento - 1 NMI), com bordo arredondado e bem assinalado na superfície externa, enquadrável no tipo COM-IT 6b, de idêntica cronologia (Bats, 1993), foi também identificado (14207). O diâmetro de bordo é de $189 \mathrm{~mm}$.

As patinae da variante COM-IT 6d, que se distinguem por um bordo curto, saliente e pendente (18798), estão também representados singularmente no Monte Molião (1 fragmento - 1 NMI). Esta variante apresenta uma cronologia mais lata do que as anteriores, centrada entre 200 e 50 a.n.e. (Bats, 1993). O diâmetro de bordo é de $249 \mathrm{~mm}$.

Finalmente, um outro fragmento de bordo (1 NMI), de secção sub-triangular e espessado externamente, poderia aproximar-se da variante COM -IT $6 g$ (24219), não obstante a saliência que exibe na sua parte inferior. A sua cronologia é idêntica à da variante anterior (Bats, 1993) e o diâmetro de bordo é de $264 \mathrm{~mm}$.

A funcionalidade deste tipo de recipientes está centrada na preparação e confecção de alimentos, sendo utilizados, sobretudo, para cozinhar / fritar, sendo posteriormente utilizados no serviço de mesa (Bats, 1993).

\subsection{Tampas}

As tampas, o segundo tipo formal mais frequente deste conjunto, exibem paredes simples e oblíquas, e um bordo de perfil arredondado (11 fragmentos - $9 \mathrm{NMI}$ ). A inclinação das suas paredes, que é consideravelmente baixa, e a simplicidade dos bordos permitem o seu enquadramento no tipo COM-IT 7a, cuja cronologia se estende entre 200 e 50 a.n.e. (Bats, 1993). Os diâmetros variam entre os 207 e os $225 \mathrm{~mm}$.

Eram utilizadas para cobrir as restantes formas da cerâmica comum itálica, sendo um elemento indispensável para a confecção de determinadas refeições.

\subsection{Patellae}

Dois outros exemplares (2 NMI) apresentam um bordo aplanado, com uma ligeira depressão na parede superior, seguindo-se uma parede de tendência vertical (10877, 15575). Assemelham-se, em termos morfológicos, às patellae da forma COM-IT
$4 \mathrm{~b}$, utilizadas entre o séc. III e finais do séc. I a.n.e. (Bats, 1993). Os diâmetros de bordo variam entre os 270 e os $315 \mathrm{~mm}$.

A sua funcionalidade estaria relacionada com a confecção de alimentos, concretamente para cozer e estufar (Bats, 1993).

\subsection{Caccabi}

Outra forma característica da cerâmica itálica que foi também documentada no Monte Molião corresponde aos caccabi ( 4 fragmentos - 4 NMI). Apresentam bordos exvertidos, de secção arredondada ou trapezoidal, com um ressalto interno bastante acentuado, que seria utilizado para colocar uma tampa. Segue-se uma parede vertical ou ligeiramente arqueada, que forma o corpo (11523, 11257). Integram-se, com grande probabilidade, no tipo COM-IT 3d, datado entre 300 e 50 a.n.e. (Bats, 1993). Os diâmetros de bordo oscilam entre os 192 e os $240 \mathrm{~mm}$.

Tal como a forma anterior, seriam utilizados na confecção de alimentos, especificamente para cozer e estufar (Bats, 1993).

\subsection{Almofariz}

Neste conjunto foi ainda possível identificar um fragmento de almofariz (1 NMI), com bordo de secção triangular e um pequeno bico saliente. Corresponde ao tipo COM-IT 8d da tipologia de Lattes, cuja cronologia está balizada entre 200 e 50 a.n.e. (Bats, 1993). O diâmetro de bordo é de $228 \mathrm{~mm}$.

A funcionalidade destes vasos, tal como já foi descrita para as produções anteriores, relaciona-se com a preparação de alimentos (triturar, moer e misturar).

\subsection{Pratos de engobe vermelho pompeiano}

A cerâmica itálica coberta no interior pelo chamado "engobe vermelho pompeiano" é consideravelmente rara entre o conjunto de Monte Molião.

As formas identificadas (3 NMI) parecem corresponder exclusivamente a pratos. $\mathrm{O}$ único fragmento de bordo apresenta-se engrossado externamente e ligeiramente côncavo no lado interno, o que permite a sua integração no tipo R-POMP 1, datado entre 100 e 50 a.n.e. (Passelac, 1993), e cuja funcionalidade é idêntica à das outras patinae itálicas já analisadas. O diâmetro de bordo é de $282 \mathrm{~mm}$.

\subsection{Fragmentos inclassificáveis}

Entre a cerâmica comum itálica, apenas um fragmento de bordo (1 NMI) não permitiu uma integração tipológica específica.

\subsection{Discussão}

A cerâmica comum itálica é, sem dúvida, uma 

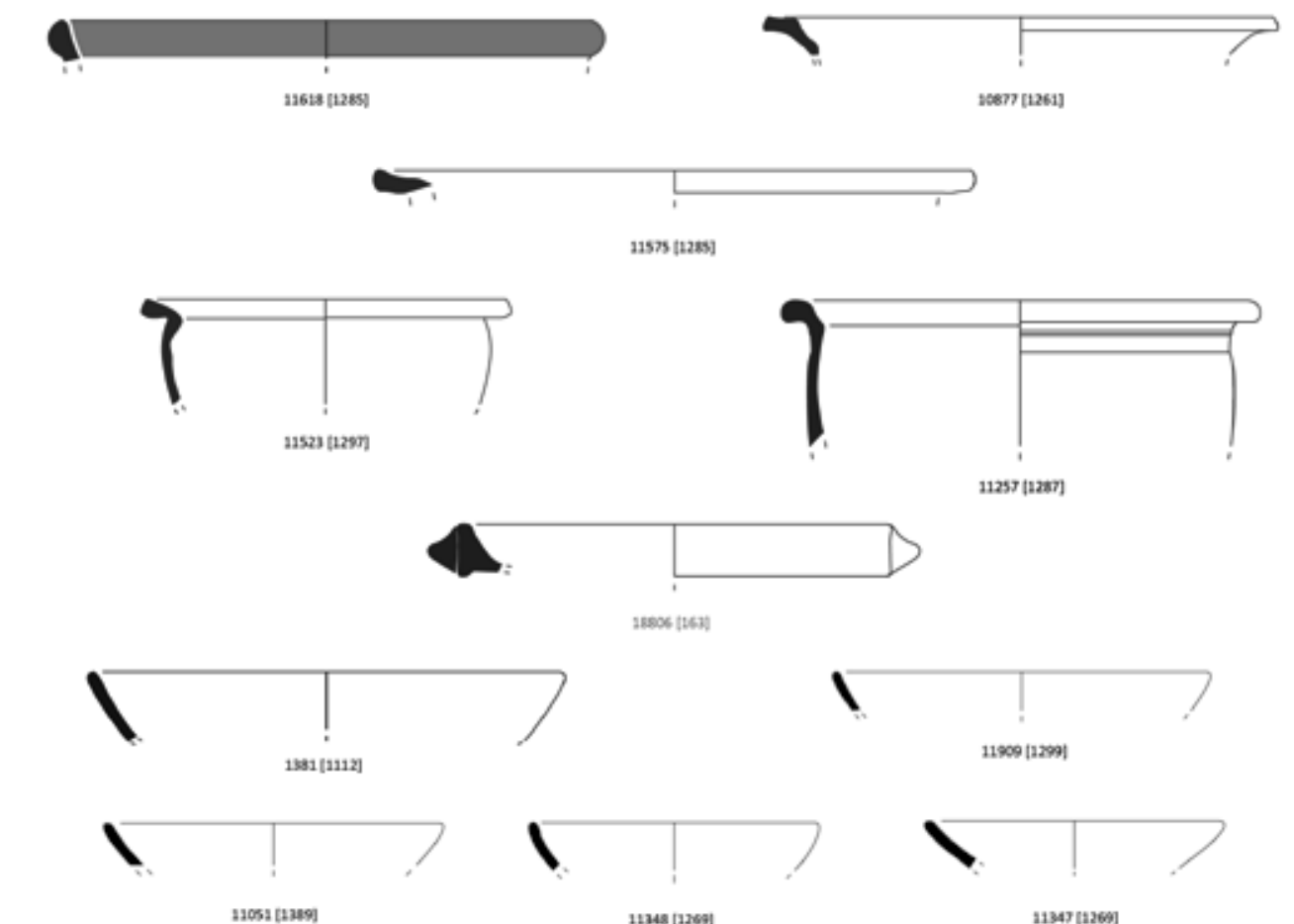

4305: [24a9)

1134 [ม269]

11349 [1269]
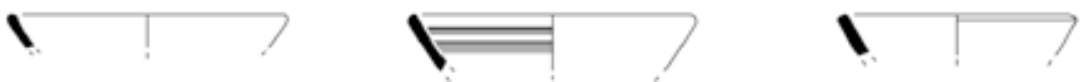

$1400012 m$

11352 [1269

1364 [1364]

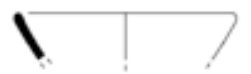

11906 [arm

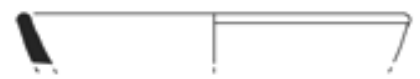

21034 [1288 ]

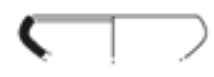

1436 [1เมี
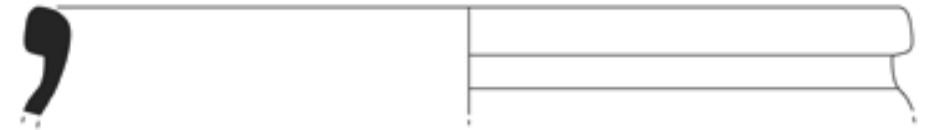

24646 [2413]

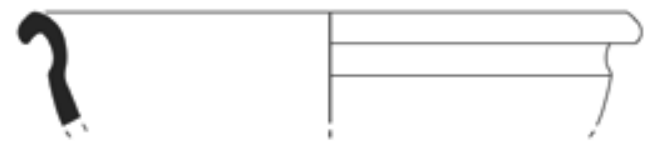

10313 [2260]

7

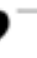

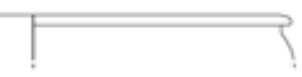

มงม โมวต]

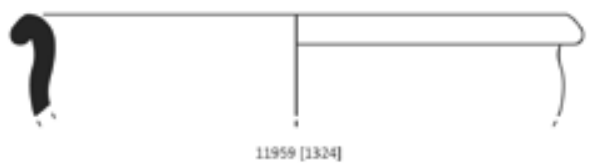

9

21943 [1299]

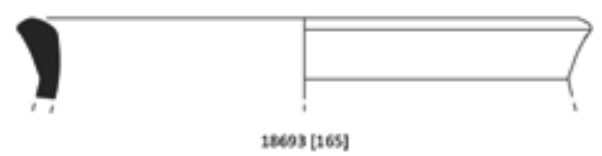

vermetho

Figura 11. Produções itálicas (prato de engobe vermelho pompeiano, patellae, caccabi e almofariz); Produções locais/regionais a torno (tigelas, taça e bacias/alguidares). 
forte inovação quando comparada ao repertório da zona meridional da Península Ibérica que transita da fase pré-romana. Esta inovação reflecte-se na introdução de novas formas, que traduzem um outra maneira de preparar e cozinhar os alimentos.

Dentro deste conjunto, as patinae constituem a forma mais bem representada (48,72\%), seguida pelas tampas $(23,08 \%)$. Recipientes utilizados para cozer e estufar, como os caccabi $(10,26 \%)$ e as patellae $(5,13 \%)$, são mais raros. Seguem-se os pratos de engobe vermelho pompeiano $(7,69 \%)$ e o almofariz $(2,56 \%)$. O único fragmento que não permitiu uma classificação concreta $(2,56 \%)$ encerra este conjunto.

\section{PRODUÇÕES LOCAIS/REgIONAIS A TORNO}

As produções locais/regionais constituem o segundo grupo mais expressivo do conjunto de cerâmica comum de Monte Molião, com 16,12\%. Apresentam uma variedade formal bastante considerável, mas a maioria dos modelos está inspirada nos materiais importados.

As suas pastas são facilmente distinguíveis pela sua natureza não calcária, textura mediamente compacta e pouca depuração, sendo os elementos não plásticos de pequena, média e, por vezes, de grande dimensão, de formato sub-arredondado. Apresentam tonalidades que variam entre o laranja e o avermelhado.

\subsection{Tigelas}

As tigelas fazem também parte das produções locais/regionais de Monte Molião, sendo um grupo relativamente bem documentado.

A forma mais frequente (44 fragmentos - 44 $\mathrm{NMI}$ ) apresenta o típico de perfil semi-hemisférico e bordo simples, de secção arredondada $(1381,11909$, 11051, 11348, 11347, 11907, 11352, 13664, 11908), que se assemelha ao tipo GDR 1.2.1 (Saéz Romero, 2005). Os diâmetros de bordo variam entre os $112 \mathrm{e}$ os $249 \mathrm{~mm}$.

Identificou-se ainda um fragmento (1 NMI) que pertence a uma tigela de bordo arredondado e indicado na superfície externa (11034). O diâmetro de bordo é de $201 \mathrm{~mm}$.

\subsection{Pequenas taças}

Este tipo morfo-funcional está representado singularmente no conjunto (1 NMI), através de um exemplar de bordo reentrante (1436), com um diâmetro de $87 \mathrm{~mm}$. As suas características são também muito similares às taças de produção gaditana.

\subsection{Bacias e/ou alguidares}

Entre os vasos que se integram neste grupo morfo-funcional, foi possível distinguir três variantes.

A primeira engloba alguidares de perfil carenado (5 fragmentos - $5 \mathrm{NMI})$, com bordos exvertidos que podem apresentar um considerável espessamente externo (24646) ou, com maior frequência, um bordo de secção arredondada, que forma um lábio pendente (10913). Os diâmetros variam entre os 312 e os $453 \mathrm{~mm}$.

$\mathrm{O}$ outro tipo de alguidares tem um perfil mais hemisférico ( 8 fragmentos - $8 \mathrm{NMI}$ ), sendo a carena inexistente ou apenas ligeiramente indicada, recordando as morfologias das produções gaditanas e do Guadalquivir. Os bordos são pouco espessados apresentam um lábio pendente (11943, 11931, 11959), variando os diâmetros entre os 255 e os 285 $\mathrm{mm}$.

A terceira variante (1 fragmento - 1NMI) exibe um ligeiro estreitamento abaixo do bordo, que é espessado e ligeiramente exvertido (18693). O diâmetro de bordo é $288 \mathrm{~mm}$.

\subsection{Pratos}

Neste grupo morfo-funcional estão presentes duas variantes distintas.

A primeira, mais abundante, é constituída pelos típicos pratos de peixe (4 fragmentos - $4 \mathrm{NMI}$ ), inspirados na forma GDR 5.1.1 de Sáez Romero e nas produções de Kuass (13731, 1431, 12762, 11127). Um deles apresenta a superfície interna revestida por um engobe vermelho-violáceo. Os diâmetros oscilam entre os $153 \mathrm{~mm}$ e os $240 \mathrm{~mm}$.

Um outro prato (1 NMI) distingue-se pelo seu bordo aplanado, que forma um pequeno lábio interno (18768), tendo um diâmetro de $153 \mathrm{~mm}$.

\subsection{Tampas}

Os escassos exemplares que puderam ser classificados como tampas (3 fragmentos - $3 \mathrm{NMI}$ ) exibem paredes rectas e simples, variando a terminação dos bordos, que podem ser apontados (12309) ou sub-rectangulares (21339), assemelhando-se às produções gaditanas. Os diâmetros variam entre os 147 e os $177 \mathrm{~mm}$.

\subsection{Potes e/ou panelas}

Tal como se verificou nas produções anteriores, este grupo morfo-funcional, maioritário neste conjunto, é aquele que engloba uma maior variedade formal, tendo sido possivel distinguir diversas variantes.

A primeira ( 2 fragmentos - $2 \mathrm{NMI}$ ) inclui potes de bordo tendencialmente recto, de secção arredon- 


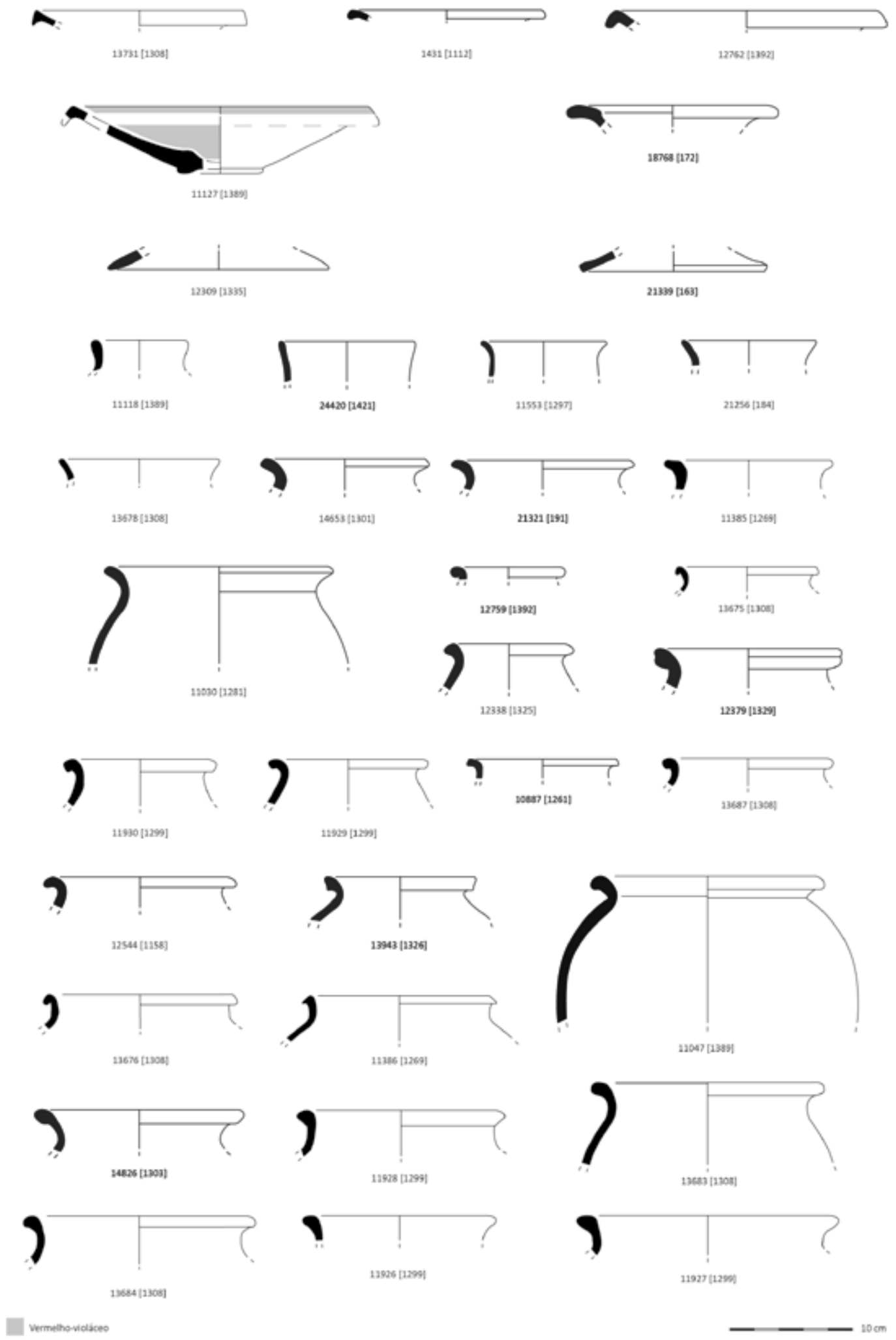

Figura 12. Produções locais/regionais a torno (pratos, tampas e potes/panelas). 
dada (11118, 24420), com diâmetros que oscilam entre os $72 \mathrm{~mm}$ e os $108 \mathrm{~mm}$.

Outros exemplares (9 fragmentos - 9 NMI) apresentam um colo tendencialmente vertical e bordo exvertido, de secção arredondada (13678, 21256, 11553). Os diâmetros variam entre os 99 e os $126 \mathrm{~mm}$.

Potes de bordo simples e claramente exvertido (12 fragmentos - $12 \mathrm{NMI}$ ), colo curto e ligeiramente estrangulado $(14653,21321,11385,11030)$ também foram identificados neste conjunto, apresentando diâmetros entre os $129 \mathrm{~mm}$ e os $177 \mathrm{~mm}$.

Outros semelhantes aos anteriores, mas que se diferenciam deles pelo seu bordo exvertido e bem assinalado na superfície externa, que por vezes chega a formar um pequeno lábio, estão muito bem representados ( 49 fragmentos - $49 \mathrm{NMI}$ ). As secções dos seus bordos são geralmente arredondadas, podendo apresentar algum engrossamento (12759, 13675, 12338, 12379, 11929, 11930, 10887, 13687, 12544, 13676, 13943, 11386, 11047). A amplitude dos diâmetros varia entre os $84 \mathrm{~mm}$ e os $177 \mathrm{~mm}$. A morfologia destes vasos mostra algumas semelhanças com o tipo 1 de Mercedes Vegas (1973)/ COM-IT 1b (Bats, 1993), não sendo de excluir a possibilidade de ter sido inspirada nos protótipos itálicos.

Distinguiu-se ainda uma outra variante, também semelhante às anteriores, mas com colos relativamente mais altos (27 fragmentos - $26 \mathrm{NMI}$ ). Os bordos são também exvertidos, bem assinalados na superfície externa, apresentando uma secção sub -arredondada (14826, 11928, 13683, 13684, 12630, 11926, 11927, 14828). Os diâmetros de bordo oscilam entre os $108 \mathrm{~mm}$ e os $228 \mathrm{~mm}$, sendo mais frequentes os mais amplos. Foi ainda possível associar um tipo específico de fundos a estes recipientes, que apresenta um pé anelar, com fundo interno aplanado (14834), e um diâmetro de $117 \mathrm{~mm}$.

Um outro grupo de potes/panelas (21 fragmentos - $21 \mathrm{NMI}$ ) bastante característico integra vasos de colo curto, ligeiramente estrangulado, com bordos exvertidos que exibem uma reentrância na superfície interna que parece destinar-se a suportar uma tampa $(11404,12163,12164,18797,13944$, 12340, 24267, 14484, 13721, 13627, 11525, 13681). Os diâmetros variam entre os $132 \mathrm{~mm}$ e os $201 \mathrm{~mm}$. Esta característica na parte interna do bordo, assim como o seu perfil têm muitas semelhanças com o tipo 2 de Mercedes Vegas (1973)/COM-IT 1b, não sendo impossível pensar numa imitação local desta forma, que, contudo, não aparece entre o repertório da cerâmica comum itálica de Monte Molião.

Potes com colo alto e vertical (2 NMI - 2 fragmentos), bordo exvertido, de secção arredondada e formando um lábio pendente $(14827,11046)$ também estão representados neste conjunto.

\subsection{Jarros}

Uma série de outros recipientes ( 5 fragmentos $5 \mathrm{NMI}$ ) exibem bordo simples e exvertidos, a partir dos quais se desenvolve um colo alto $(11400,14802$, 11103, 14843). A existência de um destes exemplares com um perfil completo permitiu-nos classificar estes fragmentos enquanto jarros, uma vez que apresentava uma única asa, de secção circular. O fundo é em ônfalo, sendo o corpo tendencialmente globular. Em dois dos fragmentos foi também possível identificar a presença de decorações pintadas, que são horizontais, com bandas castanho-avermelhadas, sobre o colo e na parte interna do bordo, ou verticais, de cor acinzentada, no colo. Os diâmetros de bordo variam entre os $123 \mathrm{~mm}$ e os $180 \mathrm{~mm}$.

\subsection{Grandes recipientes tipo dolia}

O último tipo morfo-funcional identificado entre as produções locais/regionais de Monte Molião engloba recipientes de bordo amplo e de maiores dimensões, correspondendo ao que designámos por vasos tipo dolia em outras produções (12 fragmentos - $12 \mathrm{NMI}$ ). Os seus bordos são exvertidos, podendo apresentar secções mais arredondadas ou terminações apontadas, formando um pequeno lábio (18134, 12162, 13682, 11057, 11612, 25052, 24280, 23610, 11145). Os diâmetros variam entre os $216 \mathrm{~mm}$ e os $321 \mathrm{~mm}$.

\subsection{Fragmentos inclassificáveis}

Entre os fragmentos que não permitiram uma classificação tipológica contam-se 43 fundos planos e convexos, 1 fundo em ônfalo que poderá corresponder a uma das formas de jarro, 15 fundos com pé anelar que possivelmente se relacionam com os potes/panelas de colo alto e 23 fundos (1 NMI) planos ou ligeiramente convexos que podem corresponder a tigelas.

As asas são menos frequentes (9 fragmentos) apresentando secções ovais ou circulares. Recolheram-se ainda 7 fragmentos de paredes com vestígios de pintura vermelha-acastanhada ou violácea na superfície externa.

Por último, contam-se 43 bordos (43 NMI) que não possibilitam um enquadramento específico.

9.10. Discussão

A cerâmica comum a torno de produção lo- 

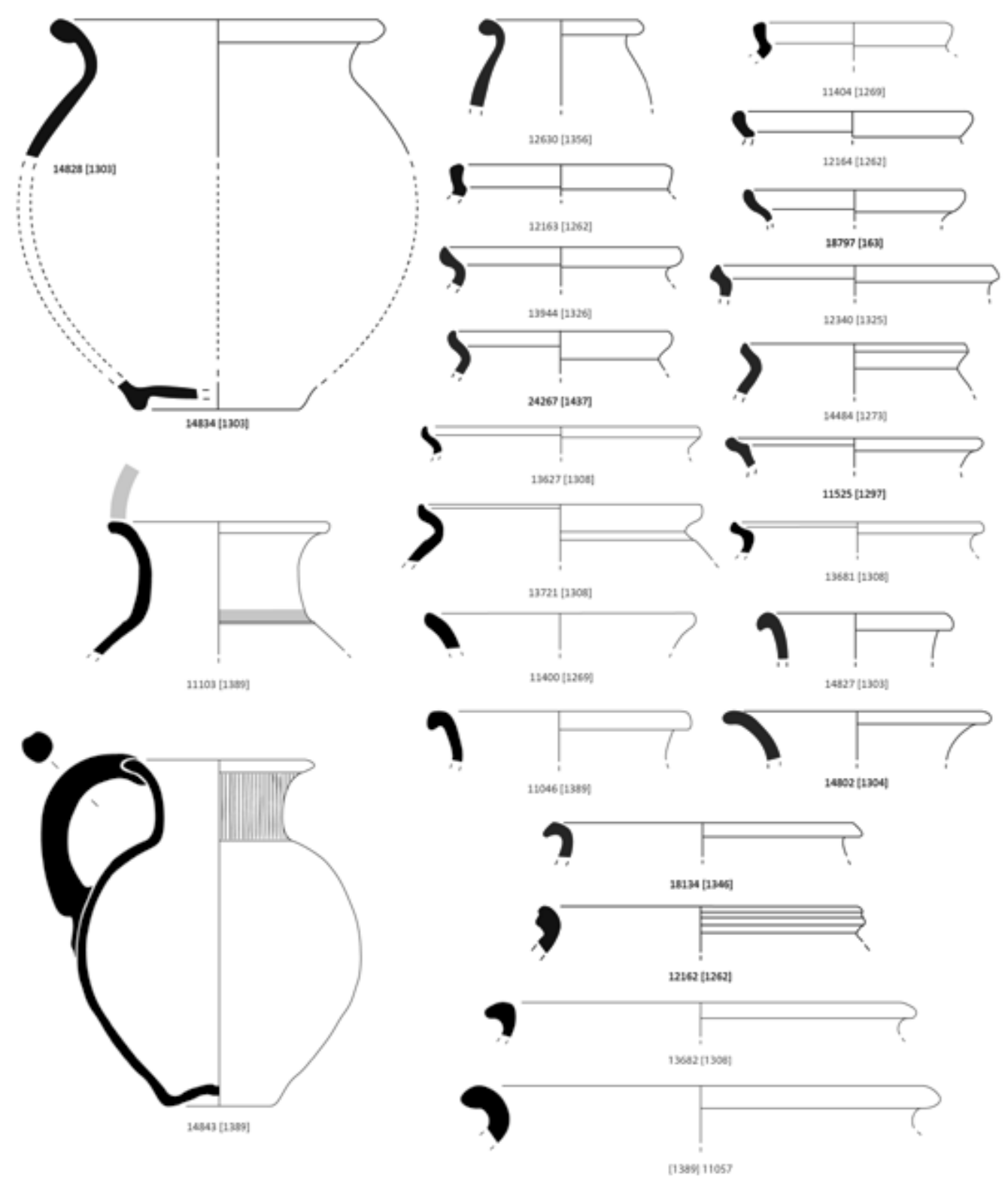

[1389) 1105]

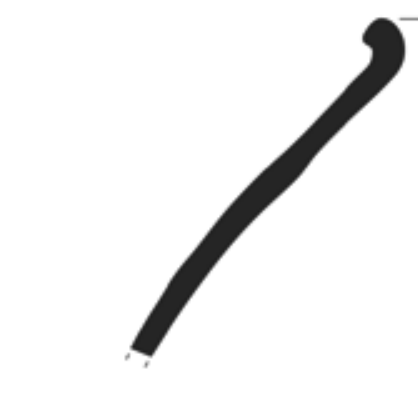

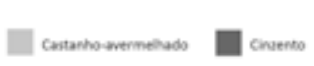

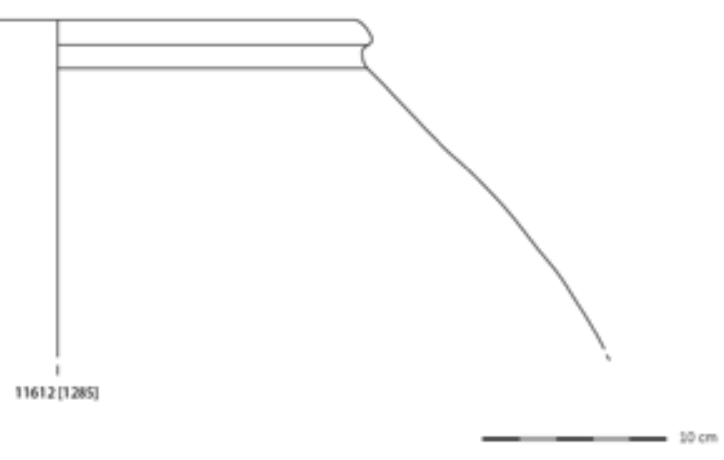

Figura 13. Produções locais/regionais a torno (potes/panelas, jarros, grandes recipientes tipo dolia). 
cal/regional é bastante significativa no conjunto presentemente analisado. Entre o seu repertório formal, que é bastante diversificado, o tipo morfo-funcional mais bem representado é o dos potes/ panelas $(48,80 \%)$. Esta situação poderá justificarse por razões de ordem prática, concretamente pela maior resistência destas produções à exposição ao fogo, derivada da considerável concentração de elementos não plásticos, por oposição, por exemplo, às produções gaditanas. Com efeito, em vários exemplares destas produções locais/regionais as superfícies externas apresentam marcas escuras que podem resultar da sua utilização como cerâmica de cozinha. Contudo, a presença de outros tipos formais, como é o caso dos jarros $(2,00 \%)$, pratos $(2,00 \%)$, taças $(0,40 \%)$ e das tigelas $(18,00 \%)$ é um claro indicador que estas produções também se destinaram ao serviço de mesa. A armazenagem está também bem documentada através dos grandes recipientes de tipo dolia $(4,80 \%)$ e das bacias e/ou alguidares $(5,60 \%)$, sendo estes últimos passíveis de serem utilizados também para outras funções, como já foi anteriormente referido. Resta referir ainda a presença de tampas que são, contudo, escassas neste conjunto (1,20\%), e dos fragmentos que não permitiram um enquadramento tipológico $(17,20 \%)$.

\section{Produções LoCAIS/REgIONAIS MANUAIS}

Entre as produções locais/regionais, identificaram-se vários exemplares de fabrico manual, que correspondem a 5,42\% do conjunto de cerâmica comum. As suas pastas apresentam tonalidades escuras, sendo pouco compactas e pouco depuradas, com elementos não plásticos de média e grande dimensão de formato sub-arredondado. A sua variedade formal é, contudo, bastante reduzida.

\subsection{Tigelas}

Entre este conjunto, destaca-se a recolha de um único fragmento (1 NMI) que correspondente a uma tigela de perfil semi-hemisférico e de bordo simples, de secção arredondada, similar ao tipo GDR 1.2.1. Infelizmente este exemplar não permitiu uma representação gráfica.

\subsection{Potes / panelas}

Entre as formas fechadas da cerâmica manual identificaram-se formas únicas no conjunto da cerâmica comum, que possivelmente têm as suas raízes no período precedente.

É o caso, por exemplo, de vasos de perfil esférico (3 fragmentos - $3 \mathrm{NMI}$ ), de bordo reentrante com secção arredondada (23335) ou aplanada (12315). Os diâmetros oscilam entre 120 e os $210 \mathrm{~mm}$.

Um outro exemplar (1 NMI) exibe paredes rectas e verticais (11289). O bordo é de secção circular, indicado na superfície externa, com $279 \mathrm{~mm}$ de diâmetro.

Recolheram-se ainda alguns fragmentos de recipientes de bordo recto (3 fragmentos - $3 \mathrm{NMI}$ ), com secção arredondada, a partir do qual se desenvolve um corpo aparentemente globular (5179, $21323,12732)$. Os diâmetros de bordo variam entre os 105 e os $183 \mathrm{~mm}$.

Seguem-se os potes/panelas de bordo simples e exvertido (62 fragmentos - 62 NMI), de secção arredondada, e corpo provavelmente globular $(14844$, 12167, 12748, 13746, 14799, 12320). Os diâmetros oscilam entre os 99 e os $195 \mathrm{~mm}$. Um destes fragmentos (5178) apresenta ainda vestígios da aplicação de um pequeno mamilo na superfície externa, na proximidade do qual se localizavam também algumas incisões, e um outro (11058) a presença de decoração estampilhada na superfície externa da parte superior do corpo, com rosetas estilizadas.

A última variante deste grupo morfo-funcional integra um vaso alto (1 NMI), de bordo simples e ligeiramente exvertido, com corpo ovalado e fundo plano (14836). O seu diâmetro de bordo é de 129 $\mathrm{mm}$.

\subsection{Jarros}

O último tipo morfo-funcional identificado entre as produções manuais de Monte Molião integra vasos ( 3 fragmentos - 3 NMI) com um colo bastante estreito e bordo exvertido, de secção sub-arredondada, por vezes indicado na superfície externa $(21320,14541,13743)$, que poderão corresponder a jarros. Os diâmetros de bordo são reduzidos, oscilando entre os 99 e os $108 \mathrm{~mm}$.

\subsection{Fragmentos inclassificáveis}

Entre os fragmentos que não permitem uma integração formal mais específica contam-se 31 fragmentos (2 NMI) de fundos planos (12168) ou convexos, uma asa de secção circular e sete (7 NMI) fragmentos de bordo.

Vários fragmentos de paredes foram também recolhidos, sendo inventariados os que exibiam traços decorativos. Em cinco identificou-se uma decoração mamilada (13748), em outros três (1 NMI), cordões plásticos, por vezes decorados com incisões (23163), que podem ter sido utilizados enquanto elemento de preensão, e ainda um com decoração incisa (12819). Mais curiosa é a presença de três 

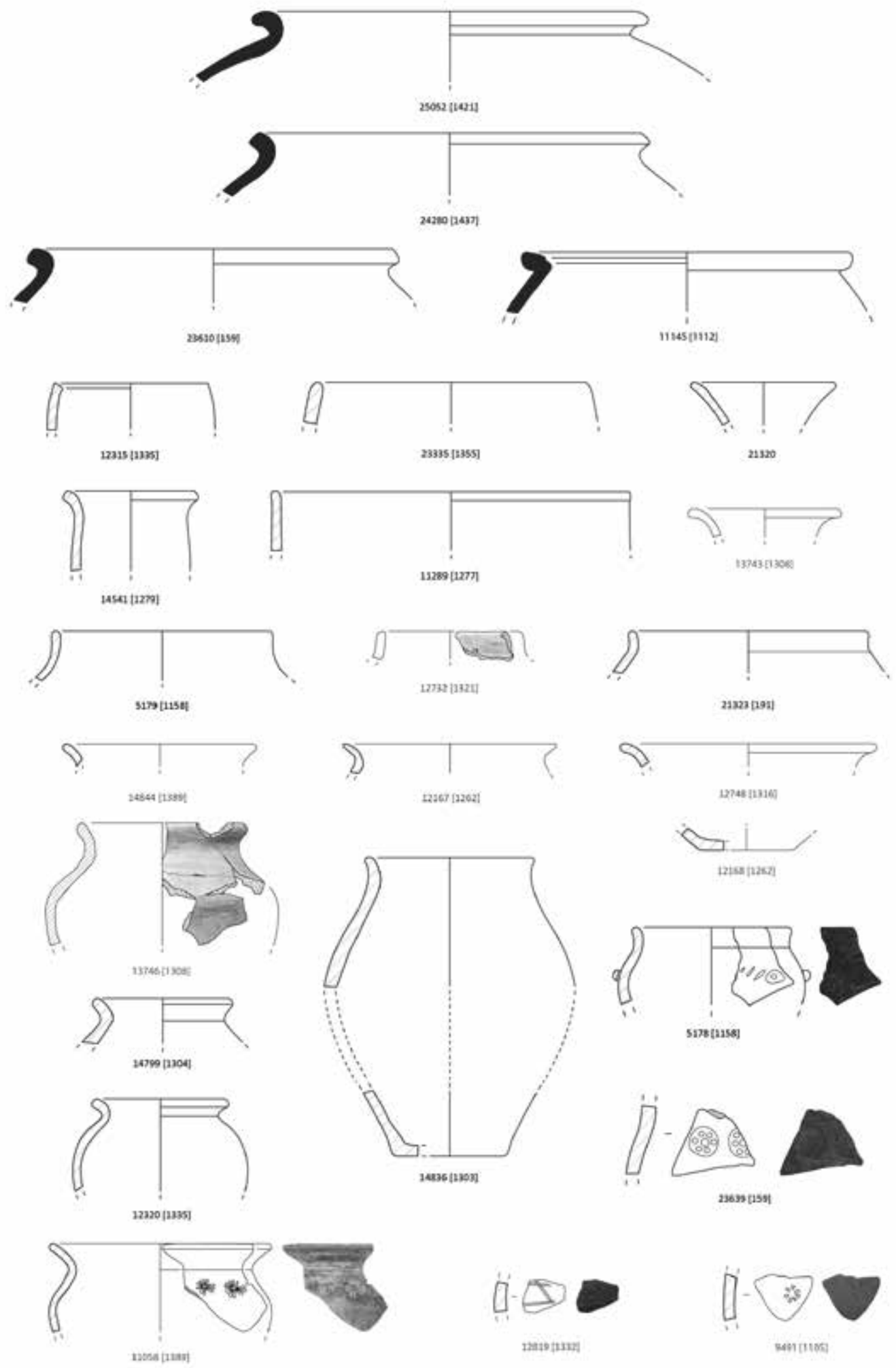

Figura 14. Produções locais/regionais a torno (grandes recipientes tipo dolia); produções manuais (vasos esféricos, vasos de perfil recto, potes/panelas, fragmentos decorados). 
fragmentos com decoração estampilhada, palmetas muito estilizadas em um dos casos (14806) e motivos circulares, possivelmente também vegetalistas, nos restantes $(23639,9491)$.

\subsection{Discussão}

As produções manuais fornecem alguns dos elementos mais interessantes na análise do conjunto de cerâmica comum de Monte Molião.

Em primeiro lugar, cabe destacar o predomínio dos recipientes de tipo pote e/ou panela $(83,33 \%)$, o que evidencia que o fabrico de vasos manuais parece ter obedecido a razões eminentemente práticas, concretamente a produção de vasos destinados à confecção de alimentos, não sendo, contudo, de excluir o seu uso no armazenamento. Estas produções, pela sua robustez e resistência ao fogo, poderiam ter sido utilizadas enquanto cerâmica de cozinha. Outros tipos formais, como é o caso dos eventuais jarros $(3,57 \%)$ e tigelas $(1,19 \%)$ são menos frequentes. Os fragmentos inclassificáveis encerram este conjunto $(11,90 \%)$.

$\mathrm{O}$ aspecto mais interessante é, contudo, a existência de quatro fragmentos com decoração estampilhada, elementos recorrentes na área "celtizante" do território português, durante o final da Idade do Ferro (Arnaud e Gamito, 1974-77; Berrocal, 1992; Fabião, 1998), mas muito raros no Algarve, com presença detectada, em fragmentos singulares, em Castro Marim e Faro, ainda que, nestes casos, o tipo de estampilhas, de pequena dimensão, esteja sobre peças pintadas em bandas e de origem gaditana (Sousa, 2009: 85). A sua presença no Monte Molião não reflecte, seguramente, uma continuidade da fase pré-romana, até porque este tipo de decoração está ausente nos contextos sidéricos deste sítio. Como tal, a incorporação destes elementos terá sido processada já em pleno período romano-republicano, situação que é, aliás, comum em outras regiões, concretamente na fachada ocidental do território actualmente português, como é o caso de Santarém (Arruda, 1999/2000) e de Coimbra (Carvalho, 1998), e do Alentejo, especificamente do Castelo da Lousa (Pinto e Schmitt, 2010).

\section{ProduçõES INDETERMinadAS}

Entre o conjunto de cerâmica comum de Monte Molião recolheu-se uma série de fragmentos que não permitiram propor uma área de origem concreta. Tal situação deve-se, sobretudo, ao estado muito alterado de algumas destas peças, provocado, possivelmente pela exposição a altas temperaturas ou a outros fenómenos pós deposicionais. Em outros casos, as características das pastas afastavam-se de todos os grupos de fabrico estabelecidos não formando, por outro lado, nenhum grupo coerente.

Contabilizaram-se alguns fragmentos de bacia/ alguidar (2 NMI), com bordo de secção arredondada e perfil moldurado $(14152,10870)$, semelhantes aos descritos para as produções Guadalquivir A. Outros exemplares ( 5 fragmentos - $5 \mathrm{NMI}$ ), com um corpo mais hemisférico e bordo exvertido, de secção sub-arredondada (14825), também foram documentados.

No tipo potes e/ou panelas, incluíram-se 2 fragmentos (2 NMI) de potes de bordo simples, exvertido e ligeiramente aplanado, seguindo-se um colo aparentemente alto $(12611,10937)$. Outros vasos exibem colos de altura média ( 7 fragmentos -7 NMI), com bordos exvertidos de terminações arredondadas (13677) e apontadas $(12697,13751)$. Uma última variante ( 2 fragmentos - $1 \mathrm{NMI}$ ) tem um bordo exvertido, de secção sub-triangular, com colo de altura média, após o qual se desenvolve um corpo aparentemente globular, marcado por uma saliência na parte superior (11513).

Dois outros (2 NMI) parecem corresponder a recipientes de grandes dimensões, de formas idênticas às já registadas nas produções anteriormente tratadas, com colos curtos e ligeiramente estrangulados, e bordos exvertidos de secção sub-arredondada $(18687,12161)$.

Resta referir um último fragmento (1 NMI), que não foi possível relacionar, ao nível da pasta, dado o seu elevado grau de depuração, com uma área concreta de produção, apesar de os paralelos tipológicos permitirem uma aproximação. Trata-se do colo de uma forma fechada, revestido com um engobe de tonalidade avermelhada na superfície interna, que teria tido como objectivo a impermeabilização do vaso (12135). Estas características permitem, apesar do seu estado de conservação, propor que se possa tratar de um fragmento de askos, de perfil muito semelhante às produções de Ibiza (Camps e Vallespir, 1974; Ramon Torres, 1997, 2012). A cronologia destas formas, apesar de remontarem à fase pré-romana, atingem ainda o período romano republicano (Ramon Torres, 2012, p. 604).

Por último, entre os fragmentos inclassificáveis contam-se oito bordos (8 NMI), cinco fundos planos ou convexos, quatro asas de secção circular e oval e cinco fragmentos de parede com vestígios de pintura acinzentada ou violácea. 


\section{CONCLUSÃO}

O estudo do vasto conjunto de cerâmica comum da fase romano-republicana de Monte Molião permite uma análise que ultrapassa a mera descrição tipológica, ajudando também a um melhor enquadramento dos circuitos comerciais que integraram este sítio e na avaliação da vivência quotidiana da sua população.

Neste contexto, importa recordar que o espólio agora estudado foi recolhido em níveis primários de ocupação, cuja cronologia (finais do séc. II a.n.e. e inícios da centúria seguinte) foi estabelecida através da análise de outros conjuntos materiais recolhidos nos mesmos estratos, concretamente a cerâmica campaniense (Dias, 2010), a de tipo Kuass (Sousa e Arruda, 2013) e os contentores anfóricos (Arruda e Sousa, 2013).

No conjunto da cerâmica comum, as produções gaditanas são claramente dominantes. Esta situação, que se verificava já durante a fase final da Idade do Ferro (Sousa, 2009; Sousa e Arruda, 2011), é clara para o período republicano, tendo Cádis mantido uma posição predominante no abastecimento de produtos manufacturados (Sousa e Arruda, 2013) e alimentares (Arruda e Sousa, 2013).

Em termos do repertório formal, as produções gaditanas da fase republicana caracterizam-se, sobretudo, pela continuidade que demonstram face ao período pré-romano. Com efeito, todas as formas identificadas têm as suas origens ainda durante a Idade do Ferro, tendo a maioria sido, inclusivamente, documentada nos contextos sidéricos de Monte Molião (Sousa e Arruda, 2011).

As restantes produções são menos expressivas no conjunto, mas ainda assim revelam uma grande variedade quanto à origem. Entre os materiais que julgamos serem originários da bacia do Guadalquivir, devem destacar-se os que foram designados como produção $\mathrm{B}$, que revelam características decorativas que parecem relacionar-se com o substrato cultural turdetano, concretamente a abundância de fragmentos pintados em bandas. Contudo, em termos da morfologia, a maioria dos tipos assemelha-se aos vasos produzidos na baía de Cádis, nos quais, contudo, estas técnicas decorativas não são tão frequentes. Deve ainda destacar-se a presença de dois grandes recipientes provenientes da chamada "Campiña Gaditana", uma área que, durante a Idade do Ferro, é bem conhecida pela sua produção oleícola, podendo propor-se que os vasos encontrados em Monte Molião pudessem ter transportado azeite dessa região durante o período romano-republicano.

No quadro das importações da Península Ibérica regista-se, por fim, a presença de vasos fabricados na fachada oriental, correspondentes a uma única forma, o kalathos. A sua identificação em contextos romano-republicanos do Extremo Ocidente é frequente, não sendo, contudo, ainda claro se reflectem uma complexificação de redes comerciais ou a circulação de indivíduos originários da chamada "área ibérica".

As relações com áreas extra-peninsulares estão representadas exclusivamente pelas produções itálicas, que, seguramente, se integram nos mesmos circuitos comerciais das ânforas e da cerâmica fina de mesa, cuja presença no sítio algarvio é muito significativa (Dias, 2010; Arruda e Sousa, 2013). A introdução da cerâmica comum itálica reflecte, contudo, alterações muito profundas, que vão além das novidades morfológicas, e que se prendem com inovações no processo de cozinhar e portanto com outros hábitos alimentares.

As produções locais, quer a torno quer de fabrico manual, constituem o segundo grupo mais bem representado, sendo aquele que evidencia, de forma mais directa, todas as transformações que se verificaram durante o período romano-republicano, uma vez que traduzem aspectos quotidianos da população. Muitas das formas identificadas (tigelas, taças, pratos, bacias/alguidares, tampas e alguns tipos de potes/panelas) copiam os modelos gaditanos. É visível, contudo, alguma originalidade nos recipientes que classificámos como jarros, que, apesar de escassos, divergem dos importados em termos de dimensão e também, em menor grau, na morfologia.

Um outro aspecto que deve ser realçado é a presença de uma série de potes/panelas de produção lo$\mathrm{cal} /$ regional, que exibem uma saliência na parte interna do bordo para encaixe de tampa, que é muito similar às panelas itálicas do tipo Vegas 2. Deve, no entanto, salientar-se que o protótipo original itálico não foi documentado no sítio algarvio. Tal situação permite colocar a possibilidade de uma parte muito significativa da população que habitava em Monte Molião estar já fortemente romanizada, ao ponto de incorporar na sua produção oleira formas típicas das práticas culinárias romanas. Um outro cenário que poderia justificar este fenómeno seria que parte desta comunidade algarvia englobasse também indivíduos itálicos ou oriundos de áreas já plenamente romanizadas. 


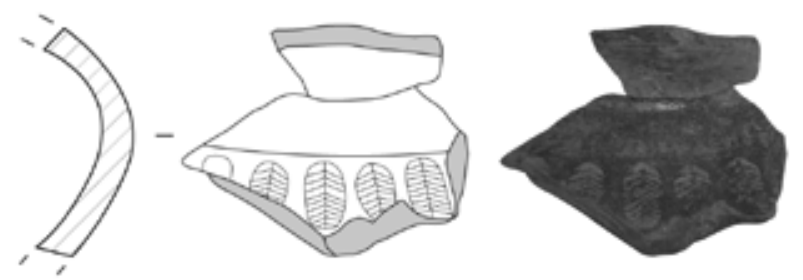

14806 [1304]
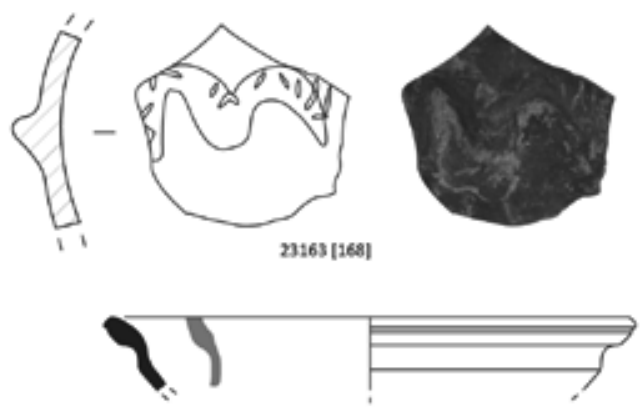

14152 [1293]
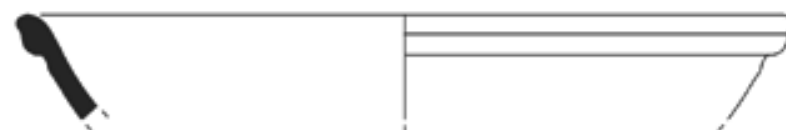

$10870[1261]$
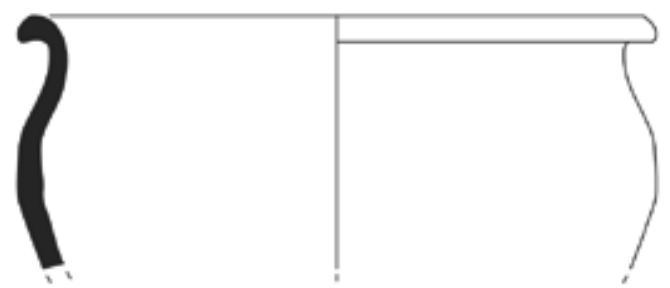

14825 [1303)

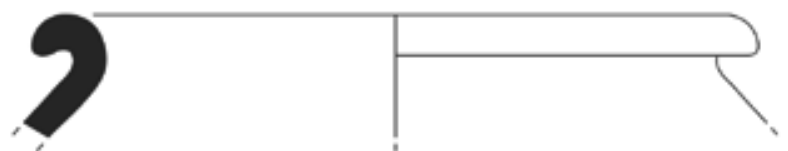

18697 (165)
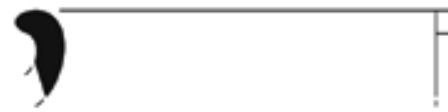

$12161[1262)$
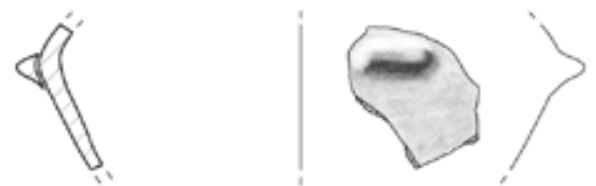

13748 [1308]

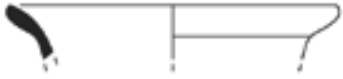

12611 (1323)

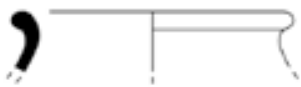

13677 [1308]
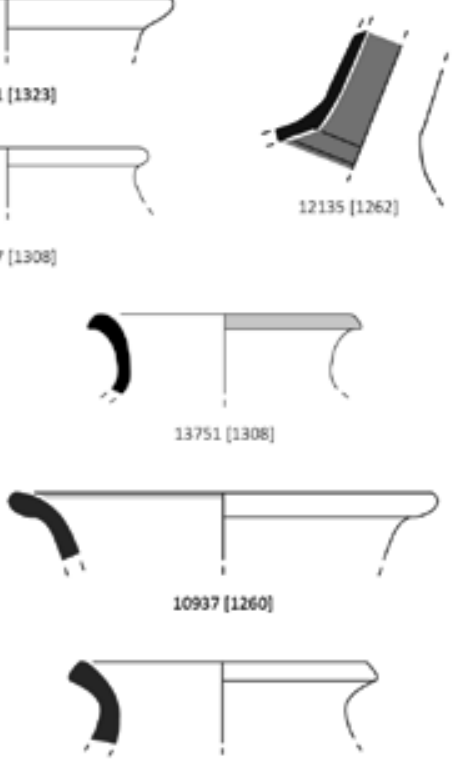

12697 (1300)
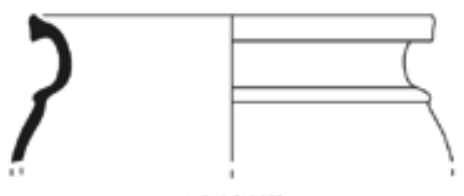

11513 [1297]

Figura 15. Produções manuais (fragmentos decorados); Produções indeterminadas (bacias/alguidares, potes/panelas e grandes recipientes tipo dolia). 
Entre os materiais de origem indeterminada deve-se, por fim, salientar-se a existência de um fragmento de askos que, pela sua morfologia, poderá aparentar-se com as produções ibicencas. Apesar de não conhecermos outros paralelos no território actualmente português, deve referir-se que um exemplar deste tipo foi já identificado na costa da Galiza (González Ruibal, 2004).

Numa análise geral, e em termos formais, o tipo mais bem representado no conjunto de cerâmica comum de Monte Molião é, sem dúvida, a tigela (48,14\%). São importadas sobretudo da área gaditana (674 NMI), sendo as produções locais/regionais a torno (45 NMI) e as manuais (1 NMI) menos frequentes. As tigelas importadas da área do Guadalqui$\operatorname{vir}(\mathrm{A}-2 \mathrm{NMI}$ e B - $17 \mathrm{NMI})$ são pouco expressivas.

$\mathrm{O}$ segundo grupo morfo-funcional mais representativo é constituído pelos potes/panelas $(25,47 \%)$. Ao contrário do que se verifica no caso anterior, as produções locais/regionais são maioritárias (a torno - $122 \mathrm{NMI}$; manuais - $73 \mathrm{NMI}$ ), facto que poderá ser justificado pela sua maior resistência a temperaturas elevadas. Estes vasos são, contudo, também importados da baía de Cádis (139 NMI) e das áreas do Guadalquivir (A - 2 NMI; B $45 \mathrm{NMI}$ ), que, considerando as suas eventuais limitações face à exposição ao fogo e ainda a presença de decorações pintadas, poderão ter sido utilizadas sobretudo para o armazenamento. Deve ainda referir-se a existência de outros potes/panelas que não possibilitaram a proposta de uma zona de origem específica (10 NMI).

Seguem-se os grandes recipientes abertos tipo bacia/alguidar $(4,36 \%)$, onde predominam as produções do Guadalquivir (A - 20 NMI; B - 10 NMI), seguindo-se as gaditanas (16 NMI), as locais/regionais (14 NMI) e as indeterminadas (7 NMI).

As restantes formas têm uma representatividade limitada no conjunto.

As tampas $(3,00 \%)$ são maioritariamente gaditanas (31 NMI), sendo os exemplares itálicos (9 NMI), do Guadalquivir (A - 3 NMI) e locais/regionais (a torno - $3 \mathrm{NMI}$ ) menos frequentes. Idêntica situação ocorre com os pratos $(2,02 \%$ - produções gaditanas - $25 \mathrm{NMI}$; locais/regionais a torno - $5 \mathrm{NMI}$; Guadalquivir B - $1 \mathrm{NMI}$ ) e com as pequenas taças (1,69\% - produções gaditanas - 23 NMI; Guadalquivir B - 2 NMI; locais/regionais - $1 \mathrm{NMI}$ ).

Os grandes recipientes de tipo dolia (1,37\%) são provenientes de várias áreas, sendo os produzidos local e/ou regionalmente mais abundantes (12
$\mathrm{NMI}$ ), quando comparados com as restantes (área de Cádis - 3 NMI; Guadalquivir A - 2 NMI; Campiña Gaditana - 2 NMI; indeterminados - $2 \mathrm{NMI}$ ). Tal como já foi referido anteriormente, é possível que a presença destas importações possa ser interpretada na óptica do envase e comercialização de produtos alimentares.

Os jarros $(1,24 \%)$, utilizados para o armazenamento de líquidos e para o seu serviço à mesa, são sobretudo provenientes da antiga Gadir (13 NMI), seguindo-se as produções locais/regionais ( $5 \mathrm{NMI}$ ) e do Guadalquivir (B - $1 \mathrm{NMI})$.

As grandes taças $(0,91 \%)$ parecem, por outro lado, corresponder a uma morfologia típica da zona andaluza (Cádis - 11 NMI; Guadalquivir A 3 NMI). Situação semelhante ocorre com os almofarizes $(0,65 \%)$, provenientes da baía gaditana $(7$ $\mathrm{NMI}$ ), do Guadalquivir (A - $2 \mathrm{NMI})$, mas também da Península Itálica (1 NMI).

As restantes formas identificadas são provenientes exclusivamente de uma única área de produção. É o caso dos kalathoi $(1,56 \%)$ da fachada oriental do território peninsular $(24 \mathrm{NMI})$, das patinae $(1,43 \%$ - 22 NMI), caccabi (0,26\% - 4 NMI) e $p a-$ tellae $(0,13 \%-2 \mathrm{NMI})$ itálicas, dos unguentários gaditanos (0,33\% - $5 \mathrm{NMI})$ e do askos (0,07\% - 1 $\mathrm{NMI})$ que pensamos ser proveniente das Ilhas $\mathrm{Ba}-$ leares.

Como fizemos já referência, o estabelecimento de paralelos não foi concretizado, uma vez que não se encontram publicados conjuntos cerâmicos com a cronologia que os espólios que estudámos detêm. Mas ao nível formal, o domínio das tigelas, na cerâmica de mesa e dos potes/panelas na de cozinha corresponde ao quadro definido para o Castelo da Lousa, que, de qualquer modo, é cronologicamente posterior (Pinto e Schmitt, 2010).

O estudo da cerâmica comum de Monte Molião permitiu constatar a existência de circuitos comerciais que não estão reflectidos em outras categorias de artefactos, como é o caso das ânforas ou da cerâmica de mesa, e que ligaram Monte Molião à área do Guadalquivir, à campiña gaditana e à fachada oriental do território peninsular.

Embora estes dados possam ser interpretados sob uma perspectiva meramente comercial, a presença de alguns elementos distintivos, como é o caso dos fragmentos de cerâmica manual decorados com estampilhas, permitem propor uma leitura alternativa. Quer a sua existência no sítio algarvio seja o resultado de uma produção local ou do seu 
transporte das áreas mais interior do sul do território português, a sua presença poderá ser uma evidência da presença de indivíduos provenientes das esferas culturais celtizantes em Monte Molião entre finais do séc. II e inícios do séc. I a.n.e. Se adicionarmos a este cenário as influências itálicas que se verificam nas produções de cariz local/regional, à grande concentração de kalathoi da chamada "área ibérica" (que é, aliás, uma das maiores conhecidas no território nacional) e até mesmo à presença de materiais que parecem intimamente relacionados com a zona turdetana do Guadalquivir, poderíamos ler uma constituição acentuadamente heterogénea da população romano-republicana que habitou este sítio algarvio.

Seguindo este raciocínio, seria tentador relacionar este fenómeno com uma dinâmica de transferência e fixação de populações em novos territórios, que se podem, quiçá, associar a veteranos de tropas auxiliares do exército romano. Os dados efectivos que ficaram registados nas fontes clássicas relatam esses episódios no âmbito da fundação de novas cidades, como é, por exemplo, o caso de Italica e Valência. Pode, no entanto, assumir-se que fenómenos semelhantes se tenham registado em escalas mais pequenas que não tiveram eco entre os autores do período romano, e que tenham feito parte de estratégias de organização e reestruturação dos territórios conquistados.

Esta proposta não implica, contudo, um estatuto militar da ocupação romano-republicana de Monte Molião, até porque evidências de armamento estão escassamente representadas no sítio algarvio. É apenas uma interpretação que poderia explicar o carácter aparentemente heterogéneo desta população, que parece integrar elementos de esferas culturais diversificadas.

Temos plena consciência do perigo que corremos em interpretar o registo arqueológico, que é, pela sua própria natureza, deficitário, e integrá-lo em leituras que envolvem aspectos de ordem étnica e cultural, até porque os mesmos argumentos que estão na base do cenário proposto anteriormente podem ser igualmente válidos se optarmos por interpretá-los na óptica de intensas redes comerciais que envolveram o sul do território português durante a fase da romanização.

A ausência de outros conjuntos coevos que permitam uma base sólida de comparação não permite verificar se a heterogeneidade do conjunto aqui analisado corresponde a uma regra ou a uma situação excepcional. O que podemos dizer é que no Castelo da Lousa, fundado em meados do século I a.n.e., a cerâmica comum é maioritariamente de produção local (84\%), sendo as importações muito raras, tendo origem apenas na baía de Cádis e na Península Itálica (Pinto e Schmitt, 2010).

No entanto, parece relativamente consensual que diferentes identidades se podem expressar através da cultura material, situação que poderá ter decorrido durante a fase romano-republicana de Monte Molião. Sendo a cerâmica comum a categoria que oferece um maior potencial na reflexão de diferenças e aspectos culturais, particularmente ao nível das produções de carácter local/regional, acreditamos que o estudo que aqui apresentamos, que implicou uma análise exaustiva e integral de todo o conjunto, pode proporcionar novos dados para o debate, análise e reconstrução do processo de romanização do sul do território actualmente português.

\section{Bibliografia}

Aranegui Gascó, C. (1996), "Los platos de peces y el más allá”, Homenaje al Profesor Manuel Fernández-Miranda, I, Complutum Extra, 401-414.

Arcelin, P. e Tuffreau-Libre, M., -Dir.- (1998), "La quantification des céramiques. Conditions et protocole", Actes de la table ronde du Centre archéologique européen du Mont Beauvray (Glux-en-Glenne, 7-9 avril 1998), Bibracte, 2. Arnaud, J. M. e Gamito, T. J. (1974/1977), "Cerâmicas estampilhadas da Idade do Ferro do sul de Portugal. I - Cabeça de Vaiamonte Monforte”, O Arqueólogo Português, 3, 7/9, 165-202

Arruda, A. M. (1999/2000), Los Fenicios en Portugal. Fenicios y mundo indígena en el centro y sur de Portugal (siglos VIII-VI a.C.), Publicaciones del Laboratorio de Arqueología de la Universidad Pompeu Fabra, Cuadernos de Arqueología Mediterránea, 5- 6, Barcelona.

Arruda, A. M. e Sousa, E. (2013), “Ânforas Republicanas de Monte Molião (Lagos, Algarve, Portugal)", Spal, 22, 101-141.

Bats, M. (1993), "Céramique commune italique", Dictionnaire des céramiques antiques (VIIe s. de n.è.) en Méditerranée nord-occidentale, Lattara, 6, 357-362.

Bernal Casasola, D., Díaz Rodríguez, J. J., Expósito Álvarez, J. A., Sáez Romero, A.M., Lorenzo Martínez, L., e Sáez Romero, A. (2003), 
Arqueologia y Urbanismo. Avance de los hallazgos de época púnica y romana en las obras de la carretera de Camposoto (San Fernando, Cádiz), Universidad de Cádiz, Cádiz.

Berrocal Rangel, L. (1992), Los pueblos célticos del Suroeste de la Península Ibérica, Complutum Extra, Madrid.

Camps Coll, J. e Vallespir Bonet, A. (1974), "La estación del Turó de ses Beies (Calvià)", Prehistoria y Arqueologia de las Islas Baleares, VI Simposio de Prehistoria Peninsular, Barcelona, 101-114.

Carvalho, P. (1998), O forum de Aeminium, Ministério da Cultura, Instituto Português dos Museus, Lisboa.

Conde Berdós, M. J. (1991), "Les produccions de kálathoi d'Empúries i la seva difusió mediterrània (segles II-I a.n.e.)", Cypsela, 9, 141-168.

Dias, V. (2010), A cerâmica campaniense de Monte Molião, Tese de Mestrado, Faculdade de Letras da Universidade de Lisboa, inédita.

Fabião, C. (1998), O Mundo Indígena e a sua Romanização na área Céltica do território hoje português, Dissertação de Doutoramento apresentada à Faculdade de Letras da Universidade de Lisboa, edição policopiada.

Ferrer Albelda, E. e García Fernández, F. (2008), "Cerámica Turdetana", Cerámicas hispanorromanas. Un estado de la cuestión (Bernal Casasola, D. e Ribera i Lacomba, A., eds.), Cádiz, 201-219.

González Ruibal, A. (2004), “Un askós ibicenco en Galicia: notas sobre el carácter del comercio púnico en el noroeste ibérico", Complutum, $15,33-43$.

González Ruibal, A., Rodríguez Martínez, R., Aboal Fernandez, R., e Castro Hierro, V. (2007), "Comercio mediterráneo en el Castro de Montalegre (Pontevedra, Galicia)”, Archivo Español de Arqueología, 80, 43-74.

Maia, M. (2007), "La pesca, a actividade conserveira e as ânforas de Tavira”, Historia de la pesca en el ámbito del Estrecho, I, 455-488.

Muccioli, G. (no prelo), I Kalathoi Iberici nell Éstremo Occidente.

Niveau De Villedary y Mariñas, A. M. (2003a), Las Cerámicas Gaditanas “Tipo Kuass”. Bases para el análisis de la Bahía de Cádiz en época púnica, Universidad de Cádiz, Cádiz.

(2003b), "El uso ritual de la vajilla cerámica en la necrópolis púnica de Cádiz”, Archivo Español de Arqueología, 76, 3-30.

Passelac, M. (1993), "Céramique à vernis rouge pompéien”, Dictionnaire des céramiques antiques (VIIe s. de n.è.) en Méditerranée nord-occidentale, Lattara, 6, 545-547.

Pinto, I. V. (2004), "Cerâmica comum de provável origem bética das villae romanas de São Cucufate”, Lusíada. Arqueologia, História de Arte e Património, 2/4, 9-29.

Pinto, I. e Schmitt, A. (2010), "Cerâmica comum”, Castelo da Lousa - Intervenções Arqueológicas de 1997 a 2002 (Alarcão, J., Carvalho, P., e Gonçalves, A., coords.), Studia Lusitana, 4, Mérida, 219-443.

Ramón Torres, J. (1997), Un taller alfarero de época púnica en Ses Figueretes (Eivissa), Eivissa.

(2012), “La cerámica púnico-ebusitana en época tardía (siglos III-I a.C.), Cerámicas hispanorromanas II. Producciones regionales (Bernal Casasola, D. e Ribera i Lacomba, A., eds.), Cádiz, 583- 617.

Sáez Romero, A. M. (2005), “Aproximación a la tipología de la cerámica común púnico-gadirita de los ss. III-II", Spal, 14, 145-177.

Sousa, E. (2009), A cerâmica de tipo Kuass no Algarve, Cadernos da Uniarq, 4, Centro de Arqueologia da Universidade de Lisboa.

Sousa, E. e Arruda, A. M. (2011), “A gaditanização do Algarve”, Mainake, 32/II, 951-974.

(2013), "A cerâmica de tipo Kuass de Monte Molião (Lagos)”, Arqueologia em Portugal. 150 anos, Actas do I Congresso da Associação dos Arqueólogos Portugueses, Lisboa, 651-659.

Sparkes, B.A. e Talcott, L. (1970), Black and plain pottery of the 6 th, 5th and 4th centuries B.C. The Athenian Agora, American School of Classical Studies at Athens, 1. XII, Princeton.

Tarradell, M. e Sanmartí, E. (1980)" L'état actuel des ètudes sur la céramique ibérique”, Céramique Hellénistiques et Romaines, Centre de Recherches d'Histoire Ancienne 36- Annales Littéraires de l'Université de Besançon, 242, 303-330.

Vegas, M. (1973), Cerámica común romana del Mediterráneo Occidental, Barcelona. 